Frankl Amaury (Orcid ID: 0000-0002-1685-2780)

Vanmaercke Matthias (Orcid ID: 0000-0002-2138-9073)

\title{
Gully prevention and control: techniques, failures and effectiveness
}

Amaury Frank| ${ }^{1,2, *}$, Jan Nyssen ${ }^{1}$, Matthias Vanmaercke ${ }^{3}$, Jean Poesen ${ }^{4,5}$

1 Department of Geography, Ghent University, Krijgslaan 281, S8, B-9000, Ghent, Belgium

2 INRAE, AMAP, IRD, CIRAD, CNRS, University Montpellier, 34000, Montpellier, France

${ }^{3}$ Department of Geography, U.R. SPHERES, University of Liège, Quartier Village O, clos Mercator J, B-4000 Liège, Belgium

4 Department of Earth and Environmental Sciences, KU Leuven, Celestijnenlaan 200E, 3001 Heverlee, Belgium

5 Maria-Curie Sklodowska University, Faculty of Earth Sciences and Spatial Management, Krasnicka 2D, 20-718, Lublin, Poland

* Corresponding author: A. Frankl, Krijgslaan 281, S8, B-9000 Ghent, Belgium. E-mail: amaury.frankl@ugent.be, phone: +329264471.

Running Head: Gully prevention and control.

Data availability statement: Data sharing is not applicable to this article as no new data were created or analysed in this study.

This article has been accepted for publication and undergone full peer review but has not been through the copyediting, typesetting, pagination and proofreading process which may lead to differences between this version and the Version of Record. Please cite this article as doi: 10.1002/esp.5033 


\section{Abstract}

Gully erosion is a major environmental problem, posing significant threats to sustainable development. However, insights on techniques to prevent and control gullying is scattered and incomplete, especially regarding failure rates and effectiveness. This review aims at addressing these issues and contribute to more successful gully prevention and control strategies by synthesizing the data from earlier studies. Preventing gully formation can be done through land use change, applying soil and water conservation techniques or by targeted measures in concentrated flow zones. The latter include measures that increase topsoil resistance and vegetation barriers. Vegetation barriers made of plant residues have the advantage of being immediately effective in protecting against erosion, but have a short life expectancy as compared to barriers made of living vegetation. Once deeply incised, the development of gullies may be controlled by diverting runoff away from the channel, but this comes at the risk of relocating the problem. Additional measures such as headcut filling, channel reshaping and headcut armouring can also be applied. To control gully channels, multiple studies report on the use of check dams and/or vegetation. Reasons for failures of these techniques depend on runoff and sediment characteristics and cross-sectional stability and micro-environment of the gully. In turn, these are controlled by external forcing factors that can be grouped into (i) geomorphology and topography, (ii) climate and (iii) the bio-physical environment. The impact of gully prevention and control techniques is addressed, especially regarding their effect on headcut retreat and network development, the trapping of sediment by check dams and reduction of catchment sediment yield. Overall, vegetation establishment in gully channels and catchments plays a key role in gully prevention and control. Once stabilized, gullies may turn into rehabilitated sites of lush vegetation 
or cropland, making the return on investment to prevent and control gullies high.

\section{Key words}

Check dam, Erosion, Failure, Sediment yield, Stabilization, Headcut, Valley-bottom,

\section{Vegetation}

\section{Introduction}

Land use and cover change has strongly altered hydrological conditions of land- and soilscapes, resulting in gully development in many regions worldwide. Deforestation, agricultural expansion and intensification, infrastructural development, and urban sprawl have widely resulted in gullying across various topographical, lithological and climatological conditions (Poesen et al., 2003; Castillo and Gómez, 2016) both in historical times (Dotterweich et al., 2003; Stankoviansky, 2003; Vanwalleghem et al., 2006) and at present (Nyssen et al., 2002; Marden et al., 2005; Zheng, 2006; Imwangana et al., 2015). Given that global environmental projections indicate that climatic and coupled hydrological systems will experience important changes over the next decades (Kundzewicz et al., 2014; Li and Fang, 2016), the need for applying more effective gully prevention and control measures becomes increasingly important. To address these challenges, many regions have implemented large-scale land rehabilitation programs (Guyassa et al., 2018; Haregeweyn et al. 2015, Hartman et al., 2016; Romero-Diaz et al., 2010). Stabilization methods such as check dams have been applied by rural communities for a long time in order to control gullies (Norton et al., 2002; Wright, Crowley and Crowley, 2008). Throughout the 20th Century, engineered control measures have been increasingly applied following rapid gully 
network developments due to unsustainable land usages (Heede, 1978; Haigh, 1984; Sheng and Liao, 1997).

Despite evident successes of gully control schemes, many interventions are only partially successful or controversial (e.g. when its application favours wealthy farmers at the expense of others) (Frankl et al., 2016; Poesen et al. 2003, Rey 2004; Sheshnev, 2017; Smit et al., 2017). Furthermore, techniques that work in a certain area may fail in another if environmental settings, particularly pedo-climatic conditions strongly differ (Rebai, Raclot and Ouezdou, 2013; Zimale et al., 2017). Also, when rural communities and their (indigenous) knowledge are weakly integrated in restoration initiatives, this may be a cause for failure (Pawluk, Sandor and Tabor, 1992). Given the high cost for applying gully prevention and control measures (Yitbarek, Belliethathan and Stringer, 2012; Quiñonero-Rubio et al., 2016), a thorough understanding of their impact on gully development and catchment sediment yield is essential. The more effective such measures are, the more likely it is that local communities will also support their implementation and maintenance. This is especially true because complex socioeconomic interactions guide the adaptation of techniques and because the cost of interventions should generally be kept as low as possible (Liniger and Critchley, 2007; Jay and Stolte, 2011; Mashi, Yaro and Jenkwe, 2015). Moreover, well-managed gullies may yield a high return on investment as they can be converted into vegetated waterways that provide multiple ecosystem services such as the restoration of perennial flow, production of fodder, fibre and wood, enhanced biodiversity and carbon sequestration (Heede, 1979; Debano and Schmidt, 1990; Rey et al. 2019; Roose, 1993; Lira-Caballero et al., 2018; Mongil-Manso et al., 2019).

Studies devoted to understand processes and factors of gully erosion in various human-environmental settings have, therefore, multiplied and recently resulted in 
several review papers (Castillo and Gómez, 2016; Poesen et al., 2003, 2006, 2011; Torri and Poesen, 2014; Vanmaercke et al., 2016). Concomitantly, several studies on gully prevention and control have also been conducted, but their results remain scattered and incomplete. This is especially so with respect to reported failures of such measures. A comprehensive review on reported failures and successes would benefit scientists, land managers and policy makers aiming to address gully erosion in the most effective and efficient way.

Therefore, the objective of this paper is to present state-of-the-art knowledge of gully prevention and control techniques. Reasons of failure will be discussed and for gully control techniques, they will be synthesised according to factors controlling gully erosion. The reported impact of techniques will be discussed by considering headcut retreat and gully development, channel aggradation and morphology, and catchment sediment yield. Section 2 explains how information was collected from literature and Section 3 provides an overview of currently applied gully prevention and control techniques. Section 4 focusses on gully prevention techniques (land use and soil and water conservation, topsoil resistance, vegetation barriers) and, especially, their effectiveness towards controlling ephemeral gully development in cropland. To note, the term 'ephemeral' is used to define gullies which are shallow enough to be erased by tillage, only to reform again in the same location by additional runoff events (Frankl et al., 2018). This is opposed to 'permanent' gullies, i.e. channels too deep to easily erase with ordinary farm tillage equipment, typically ranging from 0.5 to as much as 25-30 m depth. They often develop from bank gullies, the latter being headcuts that incise earth banks (embankments, agricultural terraces, river banks, gully banks, sunken lane banks or lynchets, Poesen et al., 2003). Although 'permanent' gullies can be persistent features of the landscape for years, decades or even centuries 
(Vanwalleghem et al., 2006; Frankl et al., 2011), it is important to note that even 'permanent' gullies can be erased. Another criterion to classify gullies is based on their location in the landscape: i.e. valley-side gullies, valley-bottom gullies, bank gullies, edge-to-field gullies and urban gullies (Poesen et al., 2003). Section 5 considers gully control techniques (in particular check dams and vegetation), failures rates and causes of failure. It also discusses the impact of control measures on headcut retreat, network development, channel aggradation and morphology, as well as catchment sediment yield.

\section{Identifying and selecting relevant literature}

We conducted a literature review on gully prevention and control techniques. The main source of information were English publications from the SCOPUS database (https://www.scopus.com/). A bibliography was created by querying SCOPUS for publications that mention 'Gully' \& 'Erosion' or 'Gully' \& 'Check Dam' in their title or key words. Variations in spelling (gulley), plural (gullies), gullying and translations (ravine, arroyo, lavaka, donga, wadi (Castillo and Gómez, 2016), were also added to the search query. We limited results to the subject areas of Earth and Planetary Sciences, Environmental Science, Agricultural and Biological Sciences, and Engineering. Citation information, abstract and key words of the resulting records were exported in *.csv format. Other relevant papers or reports that do not appear in SCOPUS, but which were known to the authors of this paper were also added to the bibliography. The resulting bibliography was reduced by searching for 'Control', 'Stabili(z)(s)ation', 'Rehabilitation', 'Reclamation', 'Prevention' in the titles, key words and abstracts. By scrutinizing all remaining abstracts, we further reduced our bibliography to a selection of 190 relevant papers and reports that focussed on prevention and control of gullies. 


\section{Overview of gully prevention and control techniques}

Since the mid-20th Century, approaches to prevent and control gullying have been presented in technical recommendations (FAO, 2020) and field guides (Sabir, Lichaa El-Khoury and Salman, 2020). By collecting evidence-based studies from all over the world, the Database on Sustainable Land Management Practices (WOCAT, 2020) considers over thirty approaches of gully control, as applied in different humanenvironmental settings. An overview of the different techniques discussed in this paper is given in Error! Reference source not found.

\section{Gully prevention}

\subsection{Techniques and their characteristics}

\subsubsection{Land use and soil and water conservation}

Gullies are typically formed as a result of high runoff rates being produced on land. Through its impact on peak runoff, land use strongly controls the topographic threshold conditions for gully head development (Torri and Poesen, 2014). For example, a conversion of forest or pasture (rangeland) to cropland can result in significant reductions of the resistance of hillslopes to gully initiation. As a result, the prevention of gully erosion mainly depends on reducing peak runoff rates. This can be achieved by land use change (Maetens et al., 2012) or through the application of soil and water conservation measures (Liniger and Critchley, 2007; Maetens, Poesen and Vanmaercke, 2012). A detailed discussion of the land use and soil and water conservation techniques and their effect on runoff production goes beyond the scope of this paper, and is comprehensively discussed in other works, such as for Africa (Wolka, Mulder and Biazin, 2018), China (Chen et al., 2020) or Europe (Maetens et 
al., 2012; Maetens, Poesen and Vanmaercke, 2012).

\subsubsection{Topsoil resistance}

Gully development can also be prevented by improving the resistance of topsoils to incision. This mainly applies to locations where gullies are recurrent in concentrated flow zones (i.e. ephemeral gullies). The following measures have been reported for cropland.

A. No tillage. No tillage plots, having compact and cohesive topsoils in valley bottoms better resist flow shear stresses exerted by concentrated flow than plots with conventional ploughing. Ploughing results in loose, less cohesive and hence, more erodible topsoils that are typically more prone to gullying (Poesen et al., 2003; Knapen et al., 2007).

B. Topsoil compaction. Building on the same principle that more cohesive topsoils have a larger resistance to incision by concentrated flow, Ouvry (1989) compacted mechanically concentrated flow zones after drilling in Northern France and observed that this treatment significantly reduced ephemeral gully development. Along the same lines, Poesen et al. (2003) concluded that knowledge of the thickness and properties of compact soil sublayers in concentrated flow zones is crucial and that any tillage operation (subsoiling) in these zones leading to a loosening of these layers should be avoided in order to prevent deep incisions by concentrated flow.

C. Grassed waterways. Grassed waterways are a commonly applied as a gully prevention approach in concentrated flow zones (Chow, Rees and Daigle, 1999; Fiener and Auerswald, 2003; Evrard et al., 2008). They are broad shallow channels, often located within large fields, with the primary purpose of 
evacuating surface runoff from cropland without causing gullying along the thalweg. To do this as effectively as possible, selected fast-growing grasses are sown in the waterway. Once established, the grass should be frequently mowed to reduce hydraulic roughness. Otherwise, the tall grass can induce sediment deposition that might damage the sward, and subsequently, gullies may develop (Fiener and Auerswald, 2003). Whereas grassed waterways are a common ephemeral gully erosion prevention practice in North America and increasingly in northern Europe, it is rarely adopted by farmers cultivating relatively small field plots or in semi-arid parts of the world where it is difficult to establish and maintain a good vegetation cover (Prosser and Slade, 1994; Poesen et al., 2003).

Overall, vegetation plays a crucial role in valley bottoms when it comes to preventing incision by concentrated flow, triggering sediment deposition and reduce the sediment connectivity of catchments (Poesen et al., 2003; Mekonnen et al., 2017; Frankl et al., 2019). Although the increased resistance to entrenchment by concentrated flow due to the presence of vegetation has been mainly attributed to aboveground biomass and its effect on overland flow energy dissipation, an increasing number of studies have also demonstrated the significant role of plant roots in reinforcing topsoils, thereby increasing cohesion (for a review, see: Vannoppen et al., 2015). Clearly, the suitability of various vegetation types as well as both the effects of the above and belowground biomass needs to be considered in gully prevention plans (De Baets et al. 2009).

D. Double drilling. Gyssels et al (2007) observed that double drilling (i.e. increasing the crops density) in concentrated flow zones reduced ephemeral 
gully erosion rates by $25 \%$. The effect of double drilling on channel development was particularly clear in the early growth stages of the wheat seedlings. This was mainly attributed to the associated higher root densities and, therefore, larger topsoil cohesion as compared to conventionally (single) drilled topsoils. As an alternative to grassed waterways, double drilling can be a measure avoiding potential losses in cropland productivity.

\subsubsection{Vegetation barriers}

Vegetation barriers are narrow strips of plants or plant residues that are increasingly

being used as measures to reduce the connectivity of catchments in terms of water and sediment fluxes (Boardman et al., 2019) (Error! Reference source not found.). They can mostly be found at plot edges where they do not to hinder farming activities too

much. Their principal function is to reduce sediment export from cropland and thus mitigate negative off-site effects of erosion (e.g., muddy floods, pollution of rivers). Being implemented in concentrated flow zones where ephemeral gullying is recurrent, they also prevent their development. This can be achieved as the barriers slow down and spread out surface runoff, and thus reduce peak runoff, force the deposition of eroded sediment and improve infiltration (Richet, Ouvry and Saunier, 2017). The selection of plants or residues depends on their local availably and suitability. Properties that determine their effectiveness are the density and the morphological traits of the plants used (stem and leaves) (Kervroëdan et al., 2018).

Barriers of plant residues can be made of wood chips, bundles of brushwood, bales straw/coconut, etc (Error! Reference source not found., Error! Reference source not found.). They have the advantage that their dense structures makes them immediately effective in protecting against erosion and that they can be rapidly applied when soil 
surfaces are temporally exposed (Haan, Barfield and Hayes, 1994).

Barriers of live vegetation can be grown from grasses, live fascines or hedgerows

(Error! Reference source not found., Error! Reference source not found.). In addition to erosion control, they are especially valuable for the creation of habitats and the strengthening of ecological connectivity. When densely grown, they will retain their functionality over long periods (Ouvry et al., 2012). Their survival is, however, often threatened by poor management. This is especially the case in cropland where they compete with crops for water, light and nutrients or where their growth can hinder farm operations and shelter perceived pests. Farmers may, therefore, trim shrubs too much to allow rejuvenation and cause (often intentionally) the vegetation to die. Flessner (1997) noted a survival rate of only $54 \%$ for willow stakes after 1.5 years.

Suitable native plants species for different environments across the globe have been proposed, taking into account their effectiveness for gully erosion control as well as other benefits (ecosystem services). Important selection criteria include the resistance to possible herbicide usage, a limited risk to house pathogens harmful to crops and being adapted to local pedoclimatic conditions (NRCS, 2010). Therefore, especially native plants species are advised. Willow (Salix alba L.) is commonly used for live fascines in the moist-temperate climate of NW Europe (Frankl et al., 2018). Other widely promoted species include stiff grasses or shrub hedges species like switchgrass (Panicum virgatum L.), miscanthus (Miscanthus sinensis Andress), vetiver (Vetiveria zizanoides (L.) Nash), eastern gamagrass (Tripsacum dactyloides L.), or rows of seabuckthorn shrubs (Hippophae rhamnoides L.) (Dewald et al., 1996; Ritchie, Kemper and Englert, 1997; Angima et al., 2002; Rachman et al., 2004; Ibanez et al., 2014; Cao et al., 2015).

This article is protected by copyright. All rights reserved. 


\subsection{Effectiveness of vegetation barriers to prevent gully development}

The effectiveness of vegetation barriers to control erosion by concentrated overland flow mainly depends on their hydraulic roughness, which impacts flow velocity and in turn soil detachment rate, sediment transport capacity and runoff infiltration (Vander Linden, 2011). The effects of (narrow) vegetation filter strips applied along contours to control overland flow and soil loss by sheet and rill erosion are well studied (Gumiere et al., 2011; Maetens et al. 2012b). However, fewer data are available for vegetation barriers installed in concentrated flow zones (Dabney et al., 2004; Vander Linden, 2011; Richet, Ouvry and Saunier, 2017; Kervroëdan et al., 2018). Available results show that newly implemented fascines from plant residues can be very effective in altering flows of water and sediment (Richet, Ouvry and Saunier, 2017), but the effectiveness of older structures is often much lower. In the long term, densely grown hedgerows may therefore be more beneficial (

) .

In a study by Frankl et al. (2018), the implementation of vegetation barriers in N-France did not have a significant effect on limiting ephemeral gully erosion. A major concern was that gaps could develop in the vegetation barriers, due to the deterioration of the vegetation barrier over time, soil piping or animal burrowing. In addition, a clear water effect caused incision just below the vegetation barriers that functioned well. These gaps created preferential flow paths that strongly reduced the effectiveness of structures made of fascines (

). Considering the volumes of sediment trapped behind vegetation barriers, the same study showed that out of 269 barriers, $47 \%$ functioned as a sediment trap. However, in S-Belgium, only $7 \%$ of the vegetation barriers were reported to function as a sediment trap (Degré and Bielders, 2016).

This article is protected by copyright. All rights reserved. 


\section{Gully control}

\subsection{Techniques and their characteristics}

\subsubsection{Runoff diversion}

In the case of deep gullies, controlling further incision may be achieved by diverting runoff away from the headcut into a diversion or retention channel (Sheng and Liao, 1997). Flow diversion is controversial as this may cause the formation of new gullies further away (Smit et al., 2017; Ben Slimane et al., 2018; Martins et al., 2019). However, when the runoff is diverted into a rehabilitating forest and on slopes where the risk of initiating gullies or landslides is limited, such diversions may, in addition to gully erosion control, result in several beneficial effects. These include groundwater recharge, sediment and nutrients deposition and improvement of vegetation growth (Descheemaeker et al. 2009, Guyassa et al., 2019). These benefits are especially pertinent in semi-arid areas.

\subsubsection{Gully reshaping}

A way of controlling gullies is by (partly) filling them up and reshaping their banks into stable slopes. The latter may be uniformly dipping slopes for small gullies or terrace steps for large gullies. The aim is to cease the erosion processes (such as plunge pool erosion, piping and gully wall collapse) that cause headcuts and banks to retreat (Poesen, Torri and Van Walleghem, 2011). Reshaping and filling alone is, however, rarely effective. If no accompanying measures are taken, a new gully will soon incise the reshaped channel (Poesen, 1989). Therefore, filling and reshaping is usually accompanied with a protective ground cover made of a geomembrane (Poesen, 1989), synthetic or biological geotextile (Fullen et al., 2011), stone rip-rap or vegetation (Ndona and Truong, 2006; de Brito Galvão et al., 2011; Ayele et al., 2018). 


\subsubsection{Check dams}

Check dams are transverse structures installed in channels to control gully erosion. They can be built from various materials, including woven wire, (brush)wood, earth, loose rock, gabion (wire net structures, filled with rocks), polyethylene bags filled with soil or stone masonry, live vegetation or other materials that are locally available (such as trash, tires or even old cars). Since the 19th Century, check dams have been widely implemented in mountain torrents and rivers to stabilize degrading channels, retain sediment and regulate sediment transport (Piton et al., 2017). Hydraulically, their aim is to reduce flow velocities and control runoff evacuation. As the stream power decreases, sedimentation behind check dams occurs. This transforms the long, uniform and steep length profile of the gully bed into successive, nearly horizontal steps (Ayres and Scoates, 1939; Heede, 1966; Hudson, 1987). As such, channel depth decreases, which can in turn strongly limit the expansion of gully networks through seepage erosion, plunge pool erosion, slumping or piping acting on the gully wall. Furthermore, filled gullies provide lateral support to adjacent slopes which reduces the chances of landsliding (Nyssen et al., 2003). In addition, vegetation growth and survival conditions improve in the vicinity of filled check dams because of their localized effect on rising groundwater tables, the availability of nutrients and fine sediments (Frankl et al., 2016; Lucas-Borja et al., 2018). The application of check dams in gullies is, therefore, often done jointly with other catchment-wide soil and water conservation measures or reforestation (Heede, 1979). Furthermore, as they are mostly conceived as temporary structures that stop channel erosion, trap sediment and facilitate the growth of a permanent vegetation cover. Once these structures collapse or rot away, the established woody vegetation would control erosion (Heede, 
1979; Böll et al., 2009).

\subsubsection{Vegetation}

A key strategy to control gullies is revegetation. Detailed investigations of plant morphologies have allowed to identify favourable traits to reduce the vulnerability of soils to water erosion and shallow mass movements (Gyssels and Poesen, 2003; De Baets et al., 2007; Vannoppen et al., 2017). Overall, selecting species for gully erosion control are based on (i) the erosion reducing and sediment trapping capacity of plants based on above-ground (e.g. stem diameter, density and stiffness, basal branching, specific leave area and density) as well as below-ground traits (e.g. root density, added cohesion, root network type, rooting depth) and (ii) the ability of plants to grow, survive and reproduce on gully floors and banks (depending on characteristics like the reproduction rate, establishment, drought resistance and tolerance, growth rate, etc.) (De Baets et al., 2009; Farhadi et al., 2018). As pointed out by Shellberg and Brooks (2013), gully banks and floors can be harsh and nutrient-poor environments, where the hydrology and soil chemical conditions may hamper vegetation growth. Given that soil conditions vary considerably between regions, several authors identified suitable species for particular environments, such as the Mediterranean (De Baets et al., 2009; Burylo, Hudek and Rey, 2011; Burylo, Dutoit and Rey, 2014; Farhadi et al., 2018) and Ethiopian highlands (Reubens et al., 2009, 2011; Talema et al., 2017; Zegeye, Langendoen, et al., 2018).

Several studies demonstrated the potential of vegetation to stabilize gullies, using various stiff grass and shrub species (Error! Reference source not found.). In the Southern French Alps, the conditions for plant establishment, survival and trapping 
efficiency have been extensively studied in experimental catchments (Rey, 2003, 2004, 2009; Rey, Isselin-Nondedeu and Bétécarrats, 2005; Burylo, Rey and Delcros, 2007; Erktan and Rey, 2013; Erktan et al., 2013, 2015; Rey and Burylo, 2014; Rey and Labonne, 2015). Key is to establish a dense cover on the gully floor, so that basal flow velocity is reduced (Erktan et al., 2013). Homogeneous covers (in the form of a brush or mat layer) with limited morphological diversity are more advantageous. As summarized by Erktan and Rey (2013), the morphological traits that define the sediment trapping efficiency of vegetation barriers vary with flow intensity. Canopy completeness is more important to trap sediment at low flow intensities, while resistance to flow (basal branching, stem density) becomes more important at high flow intensities.

\subsection{Failure rates and factors controlling the failure or success}

The failure or success of gully control measures depend on two main factors, (i) runoff and sediment characteristics of the gully system and (ii) the cross-sectional stability and micro-environment of the gully (Error! Reference source not found.). The former determines the flow energy that gully control measures have to withstand and can influences the life-expectancy of the applied measures. The latter sets the boundaries to the type of measures that could be applied without imminent risk of failure. Gully stabilization, therefore, requires a tailored approach. Both factors interact and are driven by a number of external forcing factors, which can be grouped into three main categories: (i) geomorphology and topography, (ii) climate (iii) and bio-physical environment (Error! Reference source not found.).

Understanding patterns and processes of gullying and their geomorphic context can be important to understand success and failure (Heede, 1970), but is generally 
overlooked. Deep gullies (cf. permanent gullies) usually develop according to a 'cutand-fill' cycle. Such cycle has shown to be a recurrent phenomenon in many regions, taking typically 50-100 years to be completed (Lanckriet et al., 2015; Larsen et al., 2013; Nachtergaele et al., 2002; Porter and An, 2005; Vanwalleghem et al. 2005b). Similar mechanisms have been reported for 'erosion cells' in central Australia (Pickup, 1985).

The geomorphic 'cut' phase is characterised by a rapid network development and channel degradation. It is driven by the initially steep longitudinal gradient of the gully floor at the headcut, which is geomorphologically unstable (Imeson and Kwaad, 1980; Olley and Wasson, 2003; Sidorchuk, 2006; Marden, Herzig and Arnold, 2011). Gullies that are in a 'cut' phase are more likely to experience high flow shear stresses and unstable channel cross-sections. This results in conditions unfavourable for vegetation establishment. Controlling gullies in a 'cut' phase is a difficult task that may only be successful when using 'hard' engineering approaches (e.g. check dams Error! Reference source not found.), often at high maintenance costs.

As the longitudinal profile develops a more gentle slope (through headcut retreat and channel knickpoint migration), channel degradation slows down, and the gully evolves towards a geomorphic 'fill' phase. Aggradation of the gully bed and stabilization of banks then become the dominant processes. When channel cross-sections are stabilizing, gullies develop micro-environments suitable for vegetation establishment. During a 'fill' phase, effective measures are often easier to implement (Frankl, Poesen, Haile, et al., 2013) and 'soft' engineering approaches (using vegetation, Error! Reference source not found.) can suffice to fix both channel bottom and banks and fasten aggradation of the gully bed (Harvey, 1992; Martín-Moreno et al., 2014). 
Topographic factors such as catchment area, slope gradient and gully cross-sectional shape and size exert an important control over the potential failure of gully control techniques, as they strongly influence the flow erosivity. Catchment size and slope gradient are considered good proxies of runoff volume and energy. In interaction with other driving factors, catchment size also influences the micro-environments of gullies. For example, soil moisture conditions in gullies draining small catchments may indeed be very different from those draining larger catchments, which is important for vegetation establishment and survival (See section 5.2.2.), but also for the stability of bank gullies (See section 5.2.3.).

Climate controls precipitation characteristics that have an impact on the flow volumes and velocities in gullies. Areas exposed to high rainfall intensities are likely to exhibit large peak flow discharges in gullies, making the latter hard to control. Where low temperatures prevail, snowmelt (Øygarden, 2003) or freeze-thaw cycles (Wu et al., 2008; Barnes, Luffman and Nandi, 2016) can contribute to gullying. Also the microclimatic conditions of gullies and especially gully banks also play their role, especially when vegetation is being used to control gully development (Section 5.2.2.). For example, both slope gradient and slope aspect strongly control vegetation cover and plant species diversity in dry climates (Bochet, García-Fayos and Poesen, 2009; Nadal-Romero et al., 2014).

The bio-physical environment and its management largely determine the runoff mechanisms of catchments, and thus what enters the gully. Their impact on failure rates is thus mainly indirect. Degraded catchments exposing shallow and rocky slopes may produce large runoff volumes carrying coarse bedload that scours the gully channel as well as the gully control structures (See section 5.2.1.). The characteristics of soils exposed along gullies may also require specific attention. Soils which are 
susceptible to soil piping may for example cause flows to bypass check dams (Section 5.2.1.).

\subsubsection{Check dam failure and its prevention}

As the construction of check dams requires considerable effort and investment, several authors have investigated the stability of the structures following their implementation. As sediment retention structures in (ephemeral) rivers, check dams are generally reported to remain stable, even decades after their implementation (Ran et al., 2008). In mountain torrents where debris flows can occur, check dam breaching is more frequent (Cucchiaro et al., 2019). For gullies, the failure of check dams is also considerable. According to this review, with data on fourteen reported cases of dam stability, a median of $24 \%$ of the implemented check dams breached after 1 to 45 years

(Error! Reference source not found.). Lucas-Borja et al. (2018) and Nyssen et al. (2004), who evaluated the short-term stability of numerous check dams in, respectively, Mexico and Ethiopia found that about one third of the check dams breach within 5 years after their construction. Similar results were reported for the USA (Gellis et al., 1995; Pederson, Petersen and Dierker, 2006) and China (Zeng et al., 2009). Worse, Xiang-zhou et al. (2004) estimated that a decade after the construction of hundreds of thousands of check dams in Shanbei (China), about $80 \%$ had failed.

Failures have mainly been attributed to poor design and construction (Table 3) (Zeng et al., 2009). However, the failure of check dams is also largely controlled by discharge characteristics and the stability of gully cross-sections. In this regard, the area draining to the gully, the channel steepness as well as the channel morphology (channel dimension, gully bed gradient) are important characteristics (Gellis et al., 1995; 
Nyssen et al., 2004; Lucas-Borja et al., 2018). In the SE USA, Pederson et al. (2006) identified a slope - area threshold for check dam failure (Error! Reference source not found.). This work showed that check dam failure was mainly controlled by slope steepness. This may be because, in the studied dryland environment, runoff discharge did not increase much with catchment area and because larger gullies mostly have larger width to depth ratios. The latter reduces basal flow shear stress, leading to less check dam failures (Pederson, Petersen and Dierker, 2006). In areas with exposed rock, abrasive flows (by coarse bed load) may erode dam crests and chute steps (Nyssen et al., 2017). Where dispersive or cracking soils occur, bypassing of check dams by soil piping is a frequent reason of failure (Gellis et al., 1995; Nyssen et al., 2004) (Error! Reference source not found.).

Several studies found that installing check dams can also lead to an increased erosion (clear water effect) of the channel bed downstream of the dam (Boix-Fayos et al., 2008; Polyakov et al., 2014). In Spain, channel incision was observed at $81 \%$ of the surveyed check dams in the Cárcavo catchment (Castillo et al., 2007).

Several strategies have been proposed to reduce the risk of check dam failure (Error! Reference source not found.). The most important ones rely on revegetation (Heede, 1982; Polyakov et al., 2014; Lucas-Borja et al., 2018). Vegetation is a key explanatory variable to understand check dams stability (Lucas-Borja et al., 2018), and more generally, the overall stability of the entire gully network (Zeng et al., 2009).

Given the variability of controlling factors, designing a 'one size fits all' check dam is hardly feasible. Therefore, several authors have explored the applicability of alternative check dam designs. For small gullies, permeable check dams made of 
brushwood appear to be more stable than loose rock check dams (Pederson, Petersen and Dierker, 2006). To make check dams more resistant to abrasive flows, Nyssen et al. (2017) proposed boulder-faced log dams that dissipate flow energy across the channel width. Although results were promising, $37.9 \%$ of the log dams still failed after a high magnitude runoff event. In other areas, constructing check dams with downstream energy dissipation aprons proved to work very well (Polyakov et al., 2014). To block subsurface flow where soil piping causes check dam failure, Frankl et al. (2016) inserted a geomembrane in the soil at both sides of a gabion check dam. To maintain the ecological functioning of lower reaches, Schwindt et al. (2018) proposed a hybrid check dam that blocks high sediment discharges but allows small flows and corresponding sediment fluxes to pass.

\subsubsection{Vegetation}

The establishment of vegetation in gullies is usually preceded by channel reshaping or the installation of check dams to stabilize the eroding channels (Error! Reference source not found.). When check dams are used, favourable (i.e. moist and nutrientrich) conditions are created to foster vegetation establishment and growth (Reubens et al., 2009; Nichols, McReynolds and Reed, 2012). Vegetation, in return, can fix the morphology of the engineered channel and increase sediment trapping efficiency (Thompson and Luckman, 1993; Stokes et al., 2014; Ehrensperger et al., 2015; LiraCaballero et al., 2018; Rey et al., 2019). In addition, as check dams reduce gully depth through sediment deposition, they also reduce the risk of undercutting the rootreinforced soil horizons. Such undercutting processes can be frequently observer where gullies obtain large depths (Archibold et al., 2003). As such, check dams can also increase the effectiveness of measure taken on gully banks.

This article is protected by copyright. All rights reserved. 
The application of vegetation is especially useful when the absence of nearby vegetation (on the gully banks) limits the possibility of natural colonization of the gully floor. Establishment and survival is also influenced by topographic, (micro-)climatic and pedological conditions.

Another key element is of course that the applied vegetation can resist the concentrated flow shear stresses that may develop during strong runoff events. Often, flash food regimes in large gullies hamper seedling establishment and survival (Reubens et al., 2009). Plant cuttings (e.g. of willow or jatropha) may therefore be more appropriate for early vegetation establishment in gullies (Hooke and Sandercock, 2012; Reubens et al. 2011a, Rey, 2009). Alternatively, planting stiff grass hedges has also been proposed (Dabney et al., 2004).

The gully cross-sectional shape can also be significantly affect the potential for revegetation. For example, Marden et al. (2011) report that the establishment of vegetation is easier in gullies with large top width to depth ratios because such gullies are more easily accessed by practitioners. In other socio-economic contexts, with high grazing pressures or firewood needs, the opposite may be true, and vegetation may establish more easily in steep, deep and inaccessible gullies (Frankl et al., 2019).

Slope aspect can also play an important role. For instance, in semi-arid conditions, south-facing slopes are generally drier, have a higher water stress and are, therefore, less favourable for vegetation establishment (Bochet et al. 2009, Rey and Burylo, 2014). However, under more humid and cold badland conditions, north-facing slopes may have poorer plant growth conditions than south-facing ones (Nadal-Romero et al., 2014).

After initial establishment, the effects of vegetation on soil water retention, aggregate stability, soil organic matter and nutrient content as well as on sheltering and 
microclimatic conditions may further facilitate natural colonization (Carlson and Olyphant, 1996; Reubens et al., 2009; Zhang, Xu and Wang, 2009; Xu et al., 2014; Erktan et al., 2015; Rey and Labonne, 2015).

Reported survival rates of vegetation applied in a bioengineering structure range from 0 to $100 \%$. For example, from studying 336 bioengineering structures applied in the Southern French Alps, Rey and Labonne (2015) noted a survival rate of $45 \%$ after 3-

4 years (Error! Reference source not found.A). Plant survival was mainly correlated to the presence of vegetation on gully banks (which improved micro-climatical and pedological conditions). The studied gullies had contributing catchments areas of less than 1 ha, so large flood events did not negatively affect plant survival. Nonetheless, when contributing areas became too small $(<0.1 \mathrm{ha})$ this had a negative impact on plant survival rates. Gullies with such small catchments typically have dryer gully floors and thus present a harsher environment where plant survival may drop to $0 \%$ (Rey and Burylo, 2014) (Error! Reference source not found.B).

\subsubsection{The case of valley-bottom gullies}

Valley-bottom gullies are a subject of great concern for land managers and scientists, who observe that rehabilitation attempts for such gullies often fail or even have aggravating effects. The issue has been recently raised in subhumid NW Ethiopia, where intensive soil and water conservation activities are not paying off in terms of gully stabilization (Zegeye et al., 2016; Dagnew et al., 2017; Addisie et al., 2018; Zegeye, Dessalegn, et al., 2018; Mhiret et al., 2020). This has been related to the adaptation of methods developed for the largely semi-arid NE-part of Ethiopia (Tebebu et al., 2010). In this dryer area, the focus has been on improving soil infiltration (as Horton overland flow dominates). Adopting a similar strategy in subhumid areas could 
accelerate gully erosion instead of reducing it. The problem of valley-bottom gullying is, however, not restricted to NW Ethiopia, but has been reported for other areas as well: e.g. S Africa (Boardman, Parsons and Holland, 2003), N and SE Australia (Prosser and Slade, 1994; Brooks et al., 2009), Europe (Vandekerckhove et al., 2000; Poesen et al., 2006), SW USA (Miller, 2017).

The particularity of valley-bottom gullies is that they act as efficient groundwater drains. Consequent seepage erosion can undercut gully banks, making them very susceptible to slumping (Desmyttere, 2004; Brooks et al., 2009; Mhiret et al., 2020). Furthermore, clay soils often prevail in valley bottoms. When these clays are dispersive, they can be very prone to soil piping, which in turns aggravates gullying and complicates stabilization (Imeson and Kwaad, 1980; Ding et al., 2017; Bernatek-Jakiel and Poesen, 2018). Controlling valley-bottom gullying through the use of check dams may thus prove to be difficult, unless potential risks of bypass flow are addressed (Frankl et al., 2016).

Often, the loss of vegetation on valley floors (e.g. due to increased grazing pressure) has played a key role in increasing the sensitivity to gully development (Boardman et al., 2017; Miller, 2017; Wilkinson et al., 2018). For example, Prosser and Slade (1994) indicated that critical flow shear stresses for scour in valley floors reduced with a factor 4 to 11 , following 19th Century vegetation degradation in SE Australia.

Given the role of (lack of) vegetation, several authors also point to vegetation as a key solution to address gully erosion in valley bottoms (Miller, Lord and Germanoski, 2011; Ayele et al., 2016; Shellberg et al., 2016; Frankl et al., 2019). Reducing grazing pressures (by fencing) and allowing natural vegetation regrowth may be a first approach, but must be applied in both the gullies as well as their upslope contributing areas (Shellberg and Brooks, 2013). As indicated by Frankl et al. (2019), indigenous 
knowledge systems in Ethiopia in the past may have already incorporated such strategies to control erosion in thalwegs, as they appear as dense vegetation corridors on 1930-40s aerial photographs. A key requirement, however, is to apply vegetation that develops dense and resistant stems and roots (increasing soil cohesion; De Baets et al. 2007). In particular shrubs and grasses are typically suited for this (Shellberg and Brooks, 2013). It is equally important to create homogeneous vegetation covers across the valley floor that is susceptible to gully erosion. This is well demonstrated by Grellier et al. (2012), who noticed that the transformation of a grassland into a savanna with sparse woody vegetation patches increased gullying. By draining valley bottoms using Willows (Miller, Lord and Germanoski, 2011) or Eucalyptus (Mhiret et al., 2020), groundwater levels can be lowered and consequently reduce the susceptibility of gully banks to slumping.

\subsection{Impact on gully development}

\subsubsection{Headcut retreat and network development}

One of the most visible impacts of gully control is the effect it has on channel network development. Direct measurements of headcut retreat rates following stabilization are, however, rare. This is because, on the one hand, most studies on headcut retreat mainly focus on rapidly expanding channels (Vandekerckhove et al. 2001, Frankl et al. 2012, Vanmaercke et al., 2016). On the other hand, poor results associated with headcut stabilization are rarely reported.

Nevertheless, runoff reduction in the catchment upstream of the gully head has proven to strongly reduce headcut retreat in areas without intense precipitation (He et al., 2010) or even render gully heads inactivate (Oostwoud Wijdenes et al. 2000). 
Likewise, several experiments with headcut reshaping, filling and strengthening demonstrate that such an approach can yield good results with gullying often stopping immediately and permanently (Heede, 1979; Ayele et al., 2018). However, when the filling is done by plugging loose rock or other inert material into the channel, intense erosion at the contact between the plug and the soil can cause further headcut retreat, making the effort ineffective (Poesen, 1989). As reported by the latter, this may be solved by intercepting the overland flow upslope of the headcut with a geomembrane (polyethelene sheet) and transferring the flow over the plug some distance downslope. Plugging by cornstalk mulching has also shown to yield positive results on small gullies in laboratory experiments (Xu et al., 2015). Similarly, Higaki et al. (2005) found that the rate of gully head retreat reduced by $14-73 \%$ after planting bamboo or Napier grass.

While localized morphological changes can often be directly related to stabilization measures, assessing the overall effect of measures on gully network development is overall much harder. Gully channel stabilization measures that prevent gully network expansion are generally applied in combination with the application of soil and water conservation measures within the catchment. As a result, the relative contribution of both to gully rehabilitation often remains unclear (Frankl et al., 2011; Ehrensperger et al., 2015; Guyassa et al., 2018). In addition, gully network development also depends on the geomorphic context and its long term development. The examples presented here, therefore, have to be carefully interpreted (Error! Reference source not found.).

\subsubsection{Gully aggradation and morphology}

The most direct impact of gully control measures, and in particular check dams, is gully aggradation through trapping sediment in the channel. As such, they also reduce 
sediment connectivity within catchments. We identified 14 studies that reported sediment deposition by check dams (Table 2). The median aggradation rate was 1.36 $\mathrm{Mg} \mathrm{yr}^{-1}$ per check dam. In very large gullies, aggradation rates behind newly built check dams may reach short-term maxima of up to $662.5 \mathrm{Mg} \mathrm{yr}^{-1}$ per check dam (Ayele et al., 2016). Check dams indeed typically fill in rapidly after their installation and show lower sedimentation rates later on (Polyakov et al., 2014). Nonetheless, their effect may be prolonged. In Spain, for example, large check dams (lengths 10-20 m) acted as significant sediment traps up to 30 years after their implementation (QuiñoneroRubio et al., 2016).

When check dams are conceived as a bioengineering structure (e.g. Figure 4A), mean gully aggradation rates reached $4.0 \pm 2.2 \mathrm{~cm} \mathrm{yr}^{-1}$ per dam (or $0.21 \pm 0.08 \mathrm{~m}^{3} \mathrm{yr}^{-1}$ per dam) in small gullies in the French Alps (Rey, 2009; Rey and Burylo, 2014; Rey et al., 2019). Reported channel floor aggradation rates when using only vegetation were $0.03 \pm 0.01 \mathrm{~m}^{3} \mathrm{yr}^{-1}$ per meter of gully length in the Andes (Molina et al., 2009) and 0.03 to $0.10 \mathrm{~m} \mathrm{yr}^{-1}$ in Belgium (Vanwalleghem et al., 2005). Studies in New Zealand show that reforestation of gullies an effectively stabilize gully channels (Thompson and Luckman, 1993; Marden, Herzig and Arnold, 2011).

As gullies fill in, the cross-sectional shape and longitudinal gradient of the channel are also affected. Top width to depth ratios of cross sections generally increase (Frankl, Poesen, Scholiers, et al., 2013). Gully widening may also occur by the collapse of undercut gully banks. Where steep gully banks have been fixed by vegetation, they can remain 'inactive' channels for many years (Frankl et al., 2011).

Studies report that, upon revegetation, longitudinal gully bed slopes can decrease by 2 to 36\% (Polyakov et al., 2014; Borja et al., 2018; Mongil-Manso et al., 2019). This, in combination with sediment infilling, can improve infiltration and aquifer recharge. It 
also reduces hydrological and sediment connectivity, runoff discharge as well as velocity and energy (Frankl, Poesen, Haile, et al., 2013; Guyassa et al., 2017; Borja et al., 2018; Mongil-Manso et al., 2019). This can lead to further sediment deposition on gully floors.

\subsubsection{Catchment sediment yield}

As check dams are designed to be sediment sinks and can trap significant volumes of sediment, their impact of catchment sediment yield has also been studied. Overall, our data compilation indicated that check dams can reduce catchment sediment yield by 0.1 to $203.8 \mathrm{Mg} \mathrm{ha}^{-1} \mathrm{yr}^{-1}$ (median 6.05 $\mathrm{Mg} \mathrm{ha}^{-1} \mathrm{yr}^{-1}, \mathrm{n}=23$ ), which represent a considerable reduction in sediment export by 20 to $98 \%$ (Error! Reference source not found.). As check dams mainly induce sediment deposition shortly after their installation (Ayele et al., 2016), a decrease of their effectiveness over time may be expected. A reduction of catchment sediment yield is especially observed for the smaller catchments reported in Error! Reference source not found.. However, when peak flow events cause check dam failures, the rapid release of stored sediments can result in unprecedented sediment yield peaks from 'restored' catchments (Pederson, Petersen and Dierker, 2006). Also bioengineering works applied in small gullies found in eroding catchments have proven to be often very efficient. For example, when bioengineering works result in a gully floor vegetation cover of $20-33 \%$, catchment sediment yields reduced to nearly zero (Rey, 2003, 2009).

\section{Conclusions}

Once a gully forms, its stabilization is a difficult and often a lengthy process. Preventive action is therefore suggested (Kirkby and Bracken, 2009). Several prevention 
strategies exist and especially those for cropland and ephemeral gullying have been considered in this paper (e.g. vegetation barriers). Although some measures as improving topsoil resistance have demonstrated positive effects, reducing gullying from vegetation barriers is not straightforward. Once a deep (permanent) gully is formed, the cost of doing nothing is high, both in terms of local environmental degradation and downstream impacts. Controlling already developed gullies relies on both 'hard' and 'soft' engineering techniques which consist runoff diversion, gully reshaping and/or reinforcing, implementing check dams and/or growing vegetation. Their applicability and failure rates depend on two main factors, i.e. the (i) runoff and sediment characteristics and (ii) cross-sectional stability and micro-environment of the gully. Both are driven by a number of external forcing factors that can be grouped in three categories (i) geomorphology and topography, (ii) climate (iii) and bio-physical environment. As check dams are conceived as temporary structures, the establishment of vegetation is often the best long-term strategy to secure the channel from degradation. This is especially true since failures rates of check dams are high; based on 14 studies we concluded that a median of $24 \%$ of the implemented check dams breached after 1 to 45 years. Vegetation can improve the failure rate but needs to be adapted to harsh and unstable gully environments (such the co-design approach of bioengineering check dams). Vegetation also plays and important role in treating valley-bottom gullies. Gully control measures showed positive effects on network development, gully aggradation and morphology and sediment yield. Check dams caused a median gully aggradation rate of $1.36 \mathrm{Mg} \mathrm{yr}^{-1}$ per check dam for 14 studies and sediment yield reduced by a median of $6.05 \mathrm{Mg} \mathrm{ha}^{-1} \mathrm{yr}^{-1}$ following check dam implementation $(n=23)$. In the long term, natural revegetation can transform gullies into linear oasis that become biodiversity and carbon sequestration hotspots. 
Conflict of Interest: None.

\section{Acknowledgments}

We thank the many authors listed in the references who provided copies of their work. Hanne Hendrickx is thanked from drawing Figure 1. Amaury Frankl acknowledges his postdoctoral research grant from the Research Foundation Flanders (FWO), Belgium.

\section{References}

Addisie, M. et al. (2018) 'Assessment of Practices for Controlling Shallow ValleyBottom Gullies in the Sub-Humid Ethiopian Highlands', Water, 10(4), p. 389. doi: 10.3390/w10040389.

Angima, S. D. et al. (2002) 'Use of calliandra-Napier grass contour hedges to control erosion in central Kenya', Agriculture, Ecosystems and Environment, 91(1-3), pp. 1523. doi: 10.1016/S0167-8809(01)00268-7.

Archibold, O. W. et al. (2003) 'Gully retreat in a semi-urban catchment in Saskatoon, Saskatchewan', Applied Geography, 23, pp. 261-279. doi: 10.1016/j.apgeog.2003.08.005.

Aristeidis, K. and Vasiliki, K. (2015) 'Evaluation of the post-fire erosion and flood control works in the area of Cassandra (Chalkidiki, North Greece)', Journal of Forestry Research, 26(1), pp. 209-217. doi: 10.1007/s11676-014-0005-9.

Ayele, G. K. et al. (2016) 'A biophysical and economic assessment of a communitybased rehabilitated gully in the Ethiopian highlands', Land Degradation \& Development, 27, pp. 270-280. doi: 10.1002/ldr.2425. 
Ayele, G. K. et al. (2018) 'Evaluating erosion control practices in an actively gullying watershed in the highlands of Ethiopia', Earth Surface Processes and Landforms, 43(13), pp. 2835-2843. doi: 10.1002/esp.4436.

Ayres, Q. and Scoates, D. (1939) Land drainage and reclamation. New York \& London: McGraw-Hill.

De Baets, S. et al. (2007) 'Root characteristics of representative Mediterranean plant species and their erosion-reducing potential during concentrated runoff', Plant and Soil, 294(1-2), pp. 169-183. doi: 10.1007/s11104-007-9244-2.

De Baets, S. et al. (2009) 'Methodological framework to select plant species for controlling rill and gully erosion: application to a Mediterranean ecosystem', Earth Surface Processes and Landforms, 34(June), pp. 1374-1392. doi: 10.1002/esp.

Barnes, N., Luffman, I. and Nandi, A. (2016) 'Gully erosion and freeze-thaw processes in clay-rich soils, northeast Tennessee, USA', GeoResJ. Elsevier Ltd, 9-12, pp. 6776. doi:10.1016/j.grj.2016.09.001.

Bernatek-Jakiel, A. and Poesen, J. (2018) 'Subsurface erosion by soil piping: significance and research needs', Earth-Science Reviews, 185, pp. 1107-1128. doi: 10.1016/j.earscirev.2018.08.006.

Boardman, J. et al. (2017) 'Long-term studies of land degradation in the Sneeuberg uplands, eastern Karoo, South Africa: A synthesis', Geomorphology, 285, pp. 106120. doi: 10.1016/j.geomorph.2017.01.024.

Boardman, J. et al. (2019) 'Off-site impacts of soil erosion and runoff: Why connectivity is more important than erosion rates', Soil Use and Management, 35(2), pp. 245-256. doi: $10.1111 /$ sum. 12496.

Boardman, J., Parsons, A. J. and Holland, R. (2003) 'Development of badlands and gullies in the Sneeuberg, Great Karoo, South Africa', Catena, 50, pp. 165-184. doi: 
10.1016/S0341-8162(02)00144-3.

Bochet, E., García-Fayos, P. and Poesen, J. (2009) 'Topographic thresholds for plant colonization on semi-arid eroded slopes', Earth Surface Processes and Landforms, 34, pp. 1758-1771. doi: 10.1002/esp.1860.

Boix-Fayos, C. et al. (2008) 'The impact of land use change and check-dams on catchment sediment yield', Hydrological Processes, 22(25), pp. 4922-4935. doi: 10.1002/hyp.7115.

Böll, A. et al. (2009) 'Long-term studies of joint technical and biological measures', Forest Snow and Landscape Research, 82(1), pp. 9-32. Available at: https://www.scopus.com/inward/record.uri?eid=2-s2.0-

76549096843\&partnerID=40\&md5=cc13c1fe7121d1d766c3c95f30d11418.

Borja, P. et al. (2018) 'Check dams and afforestation reducing sediment mobilization in active gully systems in the Andean mountains', Catena, 165, pp. 42-53. doi: 10.1016/j.catena.2018.01.013.

de Brito Galvão, T. C. et al. (2011) 'Straw blankets sewn with recycled plastic threads for erosion and urban sediments control', Geotechnical and Geological Engineering, 29(1), pp. 49-55. doi: 10.1007/s10706-010-9371-z.

Brooks, A. P. et al. (2009) 'Alluvial gully erosion: an example from the Mitchell fluvial megafan, Queensland, Australia', Earth Surface Processes and Landforms, 34, pp. 1951-1969 (2009). doi: 10.1002/esp.1883 Special.

Burylo, M., Dutoit, T. and Rey, F. (2014) 'Species Traits as Practical Tools for Ecological Restoration of Marly Eroded Lands', 22(5), pp. 633-640. doi: 10.1111/rec.12113.

Burylo, M., Hudek, C. and Rey, F. (2011) 'Soil reinforcement by the roots of six dominant species on eroded mountainous marly slopes (Southern Alps, France)', Catena, 84, pp. 70-78. doi: 10.1016/j.catena.2010.09.007. 
Burylo, M., Rey, F. and Delcros, P. (2007) 'Abiotic and biotic factors influencing the early stages of vegetation colonization in restored marly gullies (Southern Alps, France)', Ecological Engineering, 30, pp. 231-239. doi: 10.1016/j.ecoleng.2007.01.004.

Cao, L. et al. (2015) 'Grass hedge effects on controlling soil loss from concentrated flow: A case study in the red soil region of China', Soil and Tillage Research, 148, pp. 97-105. doi: 10.1016/j.still.2014.12.009.

Carlson, C. P. and Olyphant, G. A. (1996) 'The role of gully stabilization in abandoned mine lands reclamation', Environmental and Engineering Geoscience, 2(3), pp. 393405. Available at: https://www.scopus.com/inward/record.uri?eid=2-s2.0$0030426681 \&$ partnerID=40\&md5=88a20d5e7c7eb9a5f4024e04e4854456.

Castillo, C. and Gómez, J. A. (2016) 'A century of gully erosion research: Urgency, complexity and study approaches', Earth-Science Reviews. Elsevier B.V., 160, pp. 300-319. doi: 10.1016/j.earscirev.2016.07.009.

Castillo, V. M. et al. (2007) 'Effectiveness and geomorphological impacts of check dams for soil erosion control in a semiarid Mediterranean catchment: El Cárcavo (Murcia, Spain)', Catena, 70, pp. 416-427. doi: 10.1016/j.catena.2006.11.009.

Chen, J. et al. (2020) 'How effective are soil and water conservation measures (SWCMs) in reducing soil and water losses in the red soil hilly region of China? A metaanalysis of field plot data', Science of the Total Environment, 735(May). doi: 10.1016/j.scitotenv.2020.139517.

Chow, T. L., Rees, H. W. and Daigle, J. L. (1999) 'Effectiveness of terraces/grassed waterway systems for soil and water conservation: A field evaluation', Journal of Soil and Water Conservation, 54(3), pp. 577-583.

Cucchiaro, S. et al. (2019) 'Geomorphic effectiveness of check dams in a debris-flow 
catchment using multi-temporal topographic surveys', Catena. Elsevier, 174(November 2018), pp. 73-83. doi: 10.1016/j.catena.2018.11.004.

Dabney, S. M. et al. (2004) 'Erosion processes in gullies modified by establishing grass hedges', Transactions of the American Society of Agricultural Engineers, 47(5), pp. 1561-1571. Available at: https://www.scopus.com/inward/record.uri?eid=2-s2.011144297170\&partnerID=40\&md5=291decc628b5a4dd40371602f323f1cf.

Dagnew, D. C. et al. (2017) 'Effects of land use on catchment runoff and soil loss in the sub-humid Ethiopian highlands', Ecohydrology and Hydrobiology, 17(4), pp. 274282. doi: 10.1016/j.ecohyd.2017.07.004.

Debano, L. F. and Schmidt, L. J. (1990) 'Potential for enhancing riparian habitats in the southwestern United States with watershed practices', Forest Ecology and Management, 33-34(C), pp. 385-403. doi: 10.1016/0378-1127(90)90205-P.

Degré, A. and Bielders, C. (2016) GISER - Rapport 2016. Jambes.

Desmyttere, L. (2004) Couvert hivernal dans le bassin versant de la Aa.

Dewald, C. L. et al. (1996) 'Guidelines for the establishment of warm-season grass hedges for Erosion Control', Journal of Soil and Water Conservation, 51, pp. 16-20.

Díaz-Gutiérrez, V. et al. (2019) 'Check dams and sediment control: final results of a case study in the upper Corneja River (Central Spain)', Journal of Soils and Sediments, 19, pp. 451-466. doi: 10.1007/s11368-018-2042-z.

Ding, L. et al. (2017) 'Morphology and controlling factors of the longitudinal profile of gullies in the Yuanmou dry-hot valley', Journal of Mountain Science, 14(4), pp. 674693. doi: $10.1007 / \mathrm{s} 11629-016-4189-7$.

Dotterweich, M. et al. (2003) 'Quantifying historical gully erosion in northern Bavaria', Catena, 50, pp. 135-150. doi: 10.1016/S0341-8162(02)00142-X.

Ehrensperger, A. et al. (2015) 'Effectiveness of jatropha barriers as a soil and water 
conservation technology to rehabilitate gullies in northern Ethiopia', Journal of Soil and Water Conservation, 70(2), pp. 33A-38A. doi: 10.2489/jswc.70.2.33A.

Erktan, A. et al. (2013) 'Morphological diversity of plant barriers does not increase sediment retention in eroded marly gullies under ecological restoration', Plant and Soil, 370, pp. 653-669. doi: 10.1007/s11104-013-1738-5.

Erktan, A. et al. (2015) 'Increase in soil aggregate stability along a Mediterranean successional gradient in severely eroded gully bed ecosystems: combined effects of soil, root traits and plant community characteristics', Plant and Soil, 398, pp. 121-137. doi: 10.1007/s11104-015-2647-6.

Erktan, A. and Rey, F. (2013) 'Linking sediment trapping efficiency with morphological traits of Salix tiller barriers on marly gully floors under ecological rehabilitation', Ecological Engineering. Elsevier B.V., 51, pp. 212-220. doi: 10.1016/j.ecoleng.2012.12.003

Evrard, O. et al. (2008) 'A grassed waterway and earthen dams to control muddy floods from a cultivated catchment of the Belgian loess belt', Geomorphology, 100(3-4), pp. 419-428. doi: 10.1016/j.geomorph.2008.01.010.

FAO (2020) Principles of gully control. Rome. Available at: http://www.fao.org/docrep/006/ad082e/AD082e01.htm.

Farhadi, A. et al. (2018) 'Assessment of the potential of semi-arid plants to reduce soil erosion in the Konartakhteh watershed, Iran', Arabian Journal of Geosciences, 11: 518, pp. 1-13. doi: 10.1007/s12517-018-3805-y.

Fiener, P. and Auerswald, K. (2003) 'Effectiveness of grassed waterways in reducing runoff and sediment delivery from agricultural watersheds', Journal of Environmental Quality, 32(3), pp. 927-936.

Flessner, T. R. (1997) Plant Materials Technical note No. 19: Soil Bioengineering 
demonstration project, Coyote Creek, Lane County, Oregon: First and second year results. doi: 10.2514/2.579.

Frankl, A. et al. (2011) 'Linking long-term gully and river channel dynamics to environmental change using repeat photography (Northern Ethiopia)', Geomorphology, 129(3-4), pp. 238-251. doi: 10.1016/j.geomorph.2011.02.018.

Frankl, A., Poesen, J., Scholiers, N., et al. (2013) 'Factors controlling the morphology and volume $(\mathrm{V})$ - length $(\mathrm{L})$ relations of permanent gullies in the northern Ethiopian Highlands', Earth Surface Processes and Landforms, 38(14), pp. 1672-1684. doi: 10.1002/esp.3405.

Frankl, A., Poesen, J., Haile, M., et al. (2013) 'Quantifying long-term changes in gully networks and volumes in dryland environments: The case of Northern Ethiopia', Geomorphology, 201, pp. 254-263. doi: 10.1016/j.geomorph.2013.06.025.

Frankl, A. et al. (2016) 'Integrated solutions for combating gully erosion in areas prone to soil piping: innovations from the drylands of Northern Ethiopia', Land Degradation and Development, 27(8), pp. 1797-1804. doi: 10.1002/ldr.2301.

Frankl, A. et al. (2018) 'The success of recent land management efforts to reduce soil erosion in northern France', Geomorphology, 303, pp. 84-93. doi: 10.1016/j.geomorph.2017.11.018.

Frankl, A. et al. (2019) 'Can woody vegetation in valley bottoms protect from gully erosion? Insights using remote sensing data (1938-2016) from subhumid NW Ethiopia', Regional Environmental Change, 19, pp. 2055-2068. doi: 10.1007/s10113019-01533-4.

Fullen, M. A. et al. (2011) 'Utilising biological geotextiles: Introduction to the BORASSUS project and global perspectives', Land Degradation and Development, 22(5), pp. 453-462. doi: 10.1002/ldr.1105. 
Gellis, A. C. et al. (1995) 'Assesment of gully-control structures in the Rio Nutria Watershed, Zuni Reservation, New Mexico', Journal of the American Water Resources Association, 31(4), pp. 633-646. doi: 10.1111/j.1752-1688.1995.tb03390.x.

Grellier, S. et al. (2012) 'The indirect impact of encroaching trees on gully extension: A 64 year study in a sub-humid grassland of South Africa', Catena. Elsevier B.V., 98, pp. 110-119. doi: 10.1016/j.catena.2012.07.002.

Gumiere, S. J. et al. (2011) 'Vegetated filter effects on sedimentological connectivity of agricultural catchments in erosion modelling: A review', Earth Surface Processes and Landforms, 19(July 2010), pp. 3-19. doi: 10.1002/esp.2042.

Guyassa, E. et al. (2017) 'Effects of check dams on runoff characteristics along gully reaches, the case of Northern Ethiopia', Journal of Hydrology. Elsevier B.V., 545, pp. 299-309. doi: 10.1016/j.jhydrol.2016.12.019.

Guyassa, E. et al. (2018) 'Gully and soil and water conservation structure densities in semi-arid northern Ethiopia over the last 80 years', Earth Surface Processes and Landforms, 43(9), pp. 1848-1859. doi: 10.1002/esp.4360.

Guyassa, E. et al. (2019) 'From runoff contributor to runoff absorber: spate irrigation on exclosures in Tigray (N Ethiopia)', Ecohydrology, submitted.

Gyssels, G. et al. (2007) 'Effects of double drilling of small grains on soil erosion by concentrated flow and crop yield', Soil and Tillage Research, 93(2), pp. 379-390. doi: 10.1016/j.still.2006.05.014.

Gyssels, G. and Poesen, J. (2003) 'The importance of plant root characteristics in controlling concentrated flow erosion rates', Earth Surface Processes and Landforms, 28(4), pp. 371-384. doi: 10.1002/esp.447.

Haan, C. T., Barfield, B. J. and Hayes, J. C. (1994) Design hydrology and sedimentology for small catchments. 2nd edn. San Diego, CA, USA: Academia Press. 
Haigh, M. J. (1984) 'Ravine erosion and reclamation in India', Geoforum, 15(4), pp. $543-561$.

Hartman, B. D., Bookhagen, B. and Chadwick, O. A. (2016) 'The effects of check dams and other erosion control structures on the restoration of Andean bofedal ecosystems', Restoration Ecology, 24(6), pp. 761-772. doi: 10.1111/rec.12402.

Harvey, A. M. (1992) 'Process interactions, temporal scales and the development of hillslope gully systems: Howgill Fells, northwest England', Geomorphology, 5(3-5), pp. 323-344. doi: 10.1016/0169-555X(92)90012-D.

He, J. et al. (2010) 'Integrated erosion control measures and environmental effects in rocky mountainous areas in northern China', International Journal of Sediment Research, 25(3), pp. 294-303. doi: 10.1016/S1001-6279(10)60046-7.

Heede, B. H. (1966) US Forest Service Research Paper RM-20: Design, construction, and cost of rock check dams. Fort Collins, CO, USA.

Heede, B. H. (1970) 'Morphology of gullies in the Colorado Rocky Mountains', Hydrological Sciences Journal, 15, pp. 79-89. doi: 10.1080/02626667009493955.

Heede, B. H. (1978) 'Designing gully control systems for eroding watersheds', Environmental Management, 2(6), pp. 509-522. doi: 10.1007/BF01866709.

Heede, B. H. (1979) 'Deteriorated watersheds can be restored: A case study', Environmental Management, 3(3), pp. 271-281. doi: 10.1007/BF01866499.

Heede, B. H. (1982) 'Gully control: Determining treatment priorities for gullies in a network', Environmental Management, 6(5), pp. 441-451. doi: 10.1007/BF01871892. Higaki, D., Karki, K. K. and Gautam, C. S. (2005) 'Soil erosion control measures on degraded sloping lands: A case study in Midlands of Nepal', Aquatic Ecosystem Health \& Management, 8(3), pp. 243-249. doi: 10.1080/14634980500208184.

Hudson, N. W. (1987) Soil and water conservation in semi-arid areas. Rome: FAO 
Land and Water Development Division.

Ibanez, T. et al. (2014) 'Structural and floristic diversity of mixed tropical rain forest in

New Caledonia : new data from the New Caledonian Plant Inventory and Permanent

Plot Network (NC-PIPPN)', Applied Vegetation Science, 17, pp. 386-397. doi: 10.1111/avsc.12070.

Imeson, A. C. and Kwaad, F. J. P. M. (1980) 'Gully types and gully prediction', Geografisch Tijdschrift, 14(5), pp. 430-441.

Imwangana, F. M. et al. (2015) 'The origin and control of mega-gullies in Kinshasa (D.R. Congo)', Catena. Elsevier B.V., 125, pp. 38-49. doi: 10.1016/j.catena.2014.09.019.

Jay, M. and Stolte, O. (2011) 'A human ecology of urban ravine restoration: A New Zealand example', Urban Habitats, 6(1). Available at: https://www.scopus.com/inward/record.uri?eid=2-s2.0-

81455150201\&partnerlD=40\&md5=cf8468d648a869c0bb6737480daba4e7.

Kervroëdan, L. et al. (2018) 'Plant functional trait effects on runoff to design herbaceous hedges for soil erosion control', Ecological Engineering. Elsevier, 118(May), pp. 143-151. doi: 10.1016/j.ecoleng.2018.04.024.

Kirkby, M. J. and Bracken, L. J. (2009) 'Gully processes and gully dynamics', Earth Surface Processes and Landforms, 34, pp. 1841-1851. doi: 10.1002/esp.1866.

Kundzewicz, Z. W. et al. (2014) 'Flood risk and climate change: global and regional perspectives', Hydrological Sciences Journal. Taylor \& Francis, 59(1), pp. 1-28. doi: 10.1080/02626667.2013.857411.

Lanckriet, S. et al. (2015) 'Gully cut-and-fill cycles as related to agro-management: A historical curve number simulation in the Tigray Highlands', Earth Surface Processes and Landforms, 40(6). doi: 10.1002/esp.3687. 
Larsen, A. et al. (2013) 'The processes and timing of sediment delivery from headwaters to the trunk stream of a Central European mountain gully catchment', Geomorphology, 201, pp. 215-226. doi: 10.1016/j.geomorph.2013.06.022.

Li, Z. and Fang, H. (2016) 'Impacts of climate change on water erosion: A review', Earth-Science Reviews, 163, pp. 94-117. doi: 10.1016/j.earscirev.2016.10.004.

Vander Linden, B. (2011) Evaluatie van kleinschalige erosiedammen in de Vlaamse Ardennen Faculteit Bio-ingenieurswetenschappen Evaluatie van kleinschalige erosiedammen in de Vlaamse Ardennen. MSc thesis Faculteit Bioingenieurswetenschappen, Ghent Universiteit Gent.

Liniger, H. and Critchley, W. (eds) (2007) Where the land is greener: case studies and analysis of soil and water conservation initiatives worldwide. World Overview of Conservation Approaches and Technologies (WOCAT).

Lira-Caballero, V. G. et al. (2018) 'Initial floristic composition of rehabilitated gullies through bioengineering in the Mixteca Region, Sierra Madre del Sur, Mexico', Journal of Mountain Science, 15(10), pp. 2120-2135. doi: 10.1007/s11629-018-4899-0.

LNE (2015) 'Erosie in Vlaanderen', Departement Leefmilieu, Natuur en Energie, Afdeling Land en Bodembescherming, Ondergrond, Natuurlijke Rijkdommen, pp. 143. Available

at:

https://www.vlm.be/nl/SiteCollectionDocuments/Publicaties/mestbank/Mestrapport_2 018.pdf.

Lucas-Borja, M. E. et al. (2018) 'Exploring the influence of vegetation cover, sediment storage capacity and channel dimensions on stone check dam conditions and effectiveness in a large regulated river in México', Ecological Engineering. Elsevier, 122(March), pp. 39-47. doi: 10.1016/j.ecoleng.2018.07.025.

Maetens, W. et al. (2012) 'Effects of land use on annual runoff and soil loss in Europe 
and the Mediterranean: A meta-analysis of plot data', Progress in Physical Geography, 36(5), pp. 599-653. doi: 10.1177/0309133312451303.

Maetens, W., Poesen, J. and Vanmaercke, M. (2012) 'How effective are soil conservation techniques in reducing plot runoff and soil loss in Europe and the Mediterranean?', Earth-Science Reviews, 115(1-2), pp. 21-36. doi: 10.1016/j.earscirev.2012.08.003.

Marden, M. et al. (2005) 'Pre- and post-reforestation gully development in Mangatu Forest, East Coast, North Island, New Zealand', River Research and Applications, 21(7), pp. 757-771. doi: 10.1002/rra.882.

Marden, M., Herzig, A. and Arnold, G. (2011) 'Gully degradation, stabilisation and effectiveness of reforestation in reducing gully-derived sediment, east coast region, North Island, New Zealand', Journal of Hydrology New Zealand, 50(1), pp. 19-36. Available at: https://www.scopus.com/inward/record.uri?eid=2-s2.079960936261\&partnerlD=40\&md5=60a9042332102165135b73f5717836e.

Martín-Moreno, C. et al. (2014) 'The Ribagorda sand gully (east-central Spain): Sediment yield and human-induced origin', Geomorphology. Elsevier B.V., 224, pp. 122-138. doi: 10.1016/j.geomorph.2014.07.013.

Martins, B. et al. (2019) 'Gullies mitigation and control measures: A case study of the Seirós gullies (North of Portugal)', Physics and Chemistry of the Earth, Parts $A / B / C$, 109, pp. 26-30. doi: 10.1016/j.pce.2018.09.006.

Mashi, S. A., Yaro, A. and Jenkwe, E. D. (2015) 'Causes and consequences of gully erosion: perspectives of the local people in Dangara area, Nigeria', Environment, Development and Sustainability, 17(6), pp. 1431-1450. doi: 10.1007/s10668-0149614-х.

Mekonnen, M. et al. (2017) ‘Reducing Sediment Connectivity Through man-Made and 
Natural Sediment Sinks in the Minizr Catchment, Northwest Ethiopia', Land Degradation and Development, 28(2), pp. 708-717. doi: 10.1002/ldr.2629.

Mhiret, D. A. et al. (2020) 'A nine-year study on the benefits and risks of soil and water conservation practices in the humid highlands of Ethiopia: The Debre Mawi watershed', Journal of Environmental Management. Elsevier Ltd, 270(September), p. 110885. doi: 10.1016/j.jenvman.2020.110885.

Miller, J. R. (2017) 'Casualty of historic arroyo incision in the southwestern United States', Anthropocene. Elsevier B.V., 18, pp. 69-75. doi: 10.1016/j.ancene.2017.06.003.

Miller, J. R., Lord, M. L. and Germanoski, D. (2011) 'Meadow sensitivity to natural and anthropogenic disturbance', in Chambers, J. C. and Miller, J. R. (eds) Geomorphology, hydrology, and ecology of Great Basin meadow complexes-implications for management and restoration (Gen. Tech. Rep. RMRS-GTR-258). Fort Collins, CO, USA: Department of Agriculture, Forest Service, Rocky Mountain Research Station, pp. $68-84$.

Molina, A. et al. (2009) 'Vegetation and topographic controls on sediment deposition and storage on gully beds in a degraded mountain area', Earth Surface Dynamics, 34(January), pp. 755-767. doi: 10.1002/esp.1747.

Mongil-Manso, J. et al. (2019) 'The role of check dams in retaining organic carbon and nutrients. A study case in the Sierra de Ávila mountain range (Central Spain)', Science of the Total Environment. Elsevier B.V., 657, pp. 1030-1040. doi: S0048969718349271.

Morgan, R. P. C. (2005) Soil erosion and conservation - Third Edition. Blackwell Publishing.

Nachtergaele, J. et al. (2002) 'Medium-term evolution of a gully developed in a loess- 
derived soil', Geomorphology, 46(3-4), pp. 223-239. doi: 10.1016/S0169$555 \times(02) 00075-2$.

Nadal-Romero, E. et al. (2014) 'Effects of slope angle and aspect on plant cover and species richness in a humid Mediterranean badland', Earth Surface Processes and Landforms, 39(13), pp. 1705-1716. doi: 10.1002/esp.3549.

Ndona, A. and Truong, P. (2006) Community mobilization for the control of ravine erosion with vetiver technology in the Congo, ICV 4. Caracas, Venezuela. Available at: http://www.vetiver.org/ICV4pdfs/DC04.pdf.

Nichols, M. H., McReynolds, K. and Reed, C. (2012) 'Short-term soil moisture response to low-tech erosion control structures in a semiarid rangeland', Catena. Elsevier B.V., 98, pp. 104-109. doi: 10.1016/j.catena.2012.06.010.

Nichols, M. H. and Polyakov, V. O. (2019) 'The impacts of porous rock check dams on a semiarid alluvial fan', Science of the Total Environment. Elsevier B.V., 664, pp. 576582. doi: 10.1016/j.scitotenv.2019.01.429.

Norman, L. M. and Niraula, R. (2016) 'Model analysis of check dam impacts on longterm sediment and water budgets in Southeast Arizona, USA', Ecohydrology and Hydrobiology, 16(3), pp. 125-137. doi: 10.1016/j.ecohyd.2015.12.001.

Norton, J. B. et al. (2002) 'Native American methods for conservation and restoration of semiarid ephemeral streams', Journal of Soil and Water Conservation, 57(5), pp. 250-258. Available at: https://www.scopus.com/inward/record.uri?eid=2-s2.00036751946\&partnerID=40\&md5=f17d5f27ba98245cb730096300d3b68a.

NRCS (2010) Natural resource conservation service practice standard: Vegetation barrier - Code 601.

NRCS (2011) 'Utilization of compost filter socks', United States Department of Agriculture Natural Resources Conservation Service, Agronomy Technical Note No. 4, 
(4), pp. 1-7.

Nyssen, J. et al. (2002) 'Impact of road building on gully erosion risk: A case study from the Northern Ethiopian Highlands', Earth Surface Processes and Landforms, 27(12), pp. 1267-1283. doi: 10.1002/esp.404.

Nyssen, J. et al. (2003) 'The environmental significance of the remobilisation of ancient mass movements in the Atbara-Tekeze headwaters, northern Ethiopia', Geomorphology, 49(3-4), pp. 303-322. doi: 10.1016/S0169-555X(02)00192-7.

Nyssen, J. et al. (2004) 'The effectiveness of loose rock check dams for gully control in Tigray, northern Ethiopia', Soil Use and Management, 20, pp. 1-10. doi: 10.1079/SUM2003223.

Nyssen, J. et al. (2017) 'Boulder-faced log dams as an alternative for gabion check dams in first-order ephemeral streams with coarse bed load in Ethiopia', Journal of Hydraulic Engineering, 143(1), pp. 1-13. doi: 10.1061/(ASCE)HY.19437900.0001217

Olley, J. M. and Wasson, R. J. (2003) 'Changes in the flux of sediment in the Upper Murrumbidgee catchment, Southeastern Australia, since European settlement', Hydrological Processes, 17(16), pp. 3307-3320. doi: 10.1002/hyp.1388.

Ouvry, J. F. (1989) 'Effects of agricultural practices on cultivated land susceptibility to concentrated flow erosion. Experience in Pays de Caux (France)', ORSTOM Serie Pedologie, 25(1-2), pp. 157-169.

Ouvry, J. F. et al. (2012) Fascines \& haies pour réduire les effets du ruissellement érosif: Caractérisation de l'efficacité et conditions d'utilisation.

Øygarden, L. (2003) 'Rill and gully development during an extreme winter runoff event in Norway', Catena, 50(2-4), pp. 217-242. doi: 10.1016/S0341-8162(02)00138-8.

Pawluk, R., Sandor, J. and Tabor, J. (1992) 'The role of indigenous soil knowledge in 
agricultural development', Journal of Soil and Water Conservation, 47(4), pp. 298302. doi: 10.1002/jaba.241.

Pederson, J. L., Petersen, P. A. and Dierker, J. L. (2006) 'Gullying and erosion control at archaeological sites in Grand Canyon, Arizona', Earth Surface Processes and Landforms, 31(4), pp. 507-525. doi: 10.1002/esp.1286.

Piton, G. et al. (2017) 'Why do we build check dams in Alpine streams? An historical perspective from the French experience', Earth Surface Processes and Landforms, 42(1), pp. 91-108. doi: 10.1002/esp.3967.

Poesen, J. (1989) 'Conditions for gully formation in the Belgian loam belt and some ways to control them', Soil Technology Series 1, pp. 39-52.

Poesen, J. et al. (2003) 'Gully erosion and environmental change: Importance and research needs', Catena, 50(2-4), pp. 91-133. doi: 10.1016/S0341-8162(02)001431.

Poesen, J. et al. (2006) 'Gully erosion in Europe', in Boardman, J. and Poesen, J. (eds) Soil Erosion in Europe. Chichester: Wiley.

Poesen, J. W. A., Torri, D. B. and Van Walleghem, T. (2011) 'Gully erosion: procedures to adopt when modelling soil erosion in landscapes affected by gullying', in Morgan, R. P. C. and Nearing, M. A. (eds) Handbook of erosion modelling. Chichester, UK: Blackwell Publishing Ltd, pp. 360-386. doi: 10.1002/9781444328455.ch19.

Polyakov, V. O. et al. (2014) 'Effect of check dams on runoff, sediment yield, and retention on small semiarid watersheds', J. Soil and Water Cons., 69(5), pp. 414-421. doi: 10.2489/jswc.69.5.414.

Porter, S. C. and An, Z. (2005) 'Episodic gullying and paleomonsoon cycles on the Chinese Loess Plateau', Quaternary Research, 64(2), pp. 234-241. doi: 10.1016/j.yqres.2005.06.010.

This article is protected by copyright. All rights reserved. 
Prosser, I. P. and Slade, C. J. (1994) 'Gully formation and the role of valley-floor vegetation, southeastern Australia', Geology, 22(11), pp. 1127-1130. doi: 10.1130/0091-7613(1994)022<1127.

Quiñonero-Rubio, J. M. et al. (2016) 'Evaluation of the Effectiveness of Forest Restoration and Check-Dams to Reduce Catchment Sediment Yield', Land Degradation and Development, 27(4), pp. 1018-1031. doi: 10.1002/ldr.2331.

Rachman, A. et al. (2004) 'Soil Hydraulic Properties Influenced by Stiff-Stemmed Grass Hedge Systems', Soil Sci. Soc. Am. J., 68, pp. 1386-1393. doi: :10.2136/sssaj2004.1386.

Ramos-Diez, I. et al. (2016) 'Analysis of methods to determine the sediment retained by check dams and to estimate erosion rates in badlands', Environmental Monitoring and Assessment, 188(7), p. 405. doi: 10.1007/s10661-016-5408-y.

Ran, D. et al. (2008) 'Sediment retention by check dams in the Hekouzhen-Longmen Section of the Yellow River', International Journal of Sediment Research, 23(2), pp. 159-166. doi: 10.1016/S1001-6279(08)60015-3.

Rebai, H., Raclot, D. and Ouezdou, H. Ben (2013) 'Efficacité des aménagements de lutte contre le ravinement (Cas du bassin versant d'El Hnach, Tunisie)', Hydrological Sciences Journal, 58, pp. 1532-1541.

Reubens, B. et al. (2009) 'Establishment and management of woody seedlings in gullies in a semi-arid environment (Tigray, Ethiopia)', Plant and Soil, 324(1-2), pp. 131-156. doi: 10.1007/s11104-009-0097-8.

Reubens, B. et al. (2011) 'Tree species selection for land rehabilitation in Ethiopia: From fragmented knowledge to an integrated multi-criteria decision approach', Agroforestry Systems, 82(3), pp. 303-330. doi: 10.1007/s10457-011-9381-8.

Rey, F. (2003) 'Influence of vegetation distribution on sediment yield in forested marly 
gullies', Catena, 50, pp. 549-562. doi: 10.1016/S0341-8162(02)00121-2.

Rey, F. (2004) 'Effectiveness of vegetation barriers for marly sediment trapping', Earth

Surface Processes and Landforms, 29(9), pp. 1161-1169. doi: 10.1002/esp.1108.

Rey, F. (2009) 'A strategy for fine sediment retention with bioengineering works in eroded marly catchments in a mountainous Mediterranean climate (Southern Alps, France)', Land Degradation \& Development, 216(March), pp. 210-216. doi: 10.1002/ldr.905.

Rey, F. (2018) 'Role of bioengineering structures made of willow cuttings in marly sediment trapping: assessment of three real-size experiments in the Southern French Alps', Journal of Mountain Science, 15(2), pp. 225-236. doi: 10.1007/s11629-0174663-x.

Rey, F. et al. (2019) 'Soil and water bioengineering: Practice and research needs for reconciling natural hazard control and ecological restoration', Science of the Total Environment, 648, pp. 1210-1218. doi: 10.1016/j.scitotenv.2018.08.217.

Rey, F. and Burylo, M. (2014) 'Can bioengineering structures made of willow cuttings trap sediment in eroded marly gullies in a Mediterranean mountainous climate?', Geomorphology. Elsevier B.V., 204, pp. 564-572. doi: 10.1016/j.geomorph.2013.09.003.

Rey, F., Isselin-Nondedeu, F. and Bétécarrats, A. (2005) 'Vegetation dynamics on sediment deposits upstream of bioengineering works in mountainous marly gullies in a Mediterranean climate (Southern Alps, France)', Plant and Soil, 278, pp. 149-158. doi: $10.1007 / \mathrm{s} 11104-005-8422-3$.

Rey, F. and Labonne, S. (2015) 'Resprout and survival of willow (Salix) cuttings on bioengineering structures in actively eroding gullies in marls in a mountainous Mediterranean climate: A large-scale experiment in the Francon Catchment (Southern 
Alps, France)', Environmental Management. Springer US, 56(4), pp. 971-983. doi: 10.1007/s00267-015-0542-9.

Richet, J., Ouvry, J. and Saunier, M. (2017) 'The role of vegetative barriers such as fascines and dense shrub hedges in catchment management to reduce runoff and erosion effects: Experimental evidence of efficiency, and conditions of use', Ecological Engineering. Elsevier B.V., 103, pp. 455-469. doi: 10.1016/j.ecoleng.2016.08.008.

Ritchie, J. C., Kemper, W. D. and Englert, J. M. (1997) 'Narrow stiff grass hedges for erosion control', in Human impact on erosion and sedimentation. Proc. international symposium, Rabat, Morocco, 1997, pp. 195-203.

Romero-Diaz, A., Belmonte-Serrato, F. and Ruiz-Sinoga, D. (2010) 'The geomorphic impact of afforestations on soil erosion in Southeast Spain', Land Degradation and Development, 21(188-195), pp. 188-195. doi: 10.1002/ldr.946.

Roose, E. (1993) 'Water and soil fertility management: a new approach to fight erosion and improve land productivity', in Acceptance of Soil and Water Conservation: Strategies and Technologies. DITSL: DITSL, pp. 129-164.

Sabir, M., Lichaa El-Khoury, D. and Salman, M. (2020) Field guide for hill land reclamation and water management, FAO. Beirut. doi: 10.4060/ca8381en.

Schwindt, S. et al. (2018) 'Sediment traps with guiding channel and hybrid check dams improve controlled sediment retention', Natural Hazards and Earth System Sciences, 18(2), pp. 647-668. doi: 10.5194/nhess-18-647-2018.

Sharpley, A. et al. (1996) 'Gully treatment and water quality in the Southern Plains', J. Soil and Water Cons., 51(6), pp. 498-503.

Shellberg, B. J. G. and Brooks, A. P. (2013) Alluvial gully prevention and rehabilitation options for reducing sediment loads in the Normanby Catchment and Northern Australia (Final Report for the Australian Government's Caring for our Country - Reef 
Rescue Initiative). Available at: http://www.capeyorkwaterquality.info/references/cywq223.

Shellberg, J. G. et al. (2016) 'Degradation of the Mitchell River fluvial megafan by alluvial gully erosion increased by post-European land use change, Queensland, Australia', Geomorphology, 266, pp. 105-120. doi: 10.1016/j.geomorph.2016.04.021. Sheng, J. and Liao, A. (1997) 'Erosion control in South China', Catena, 29, pp. 211221. doi: 10.1016/S0341-8162(96)00057-4.

Sheshnev, A. S. (2017) 'Man-caused landslides in gully systems of the Saratov city: The Glebuchev ravine case study', Geomorfologiya, 3, pp. 30-37. doi: $10.7868 / \mathrm{S} 0435428117030038$.

Sidorchuk, A. (2006) 'Stages in gully evolution and self-organized criticality', Earth Surface Processes and Landforms, 31, pp. 1329-1344. doi: 10.1002/esp.1334 1329.

Ben Slimane, A. et al. (2018) 'Combining field monitoring and aerial imagery to evaluate the role of gully erosion in a Mediterranean catchment (Tunisia)', Catena, 170, pp. 73-83. doi: 10.1016/j.catena.2018.05.044.

Smit, H. et al. (2017) 'The political morphology of drainage - How gully formation links to state formation in the Choke Mountains of Ethiopia', World Development. The Authors, 98, pp. 231-244. doi: 10.1016/j.worlddev.2017.04.031.

Sran, D. S., Kukal, S. S. and Singh, M. J. (2012) 'Run-off and sediment yield in relation to differential gully-plugging schemes in micro-catchments of Shiwaliks in the lower Himalayas', Archives of Agronomy and Soil Science, 58(11), pp. 1317-1327. doi: 10.1080/03650340.2011.577422.

Stankoviansky, M. (2003) 'Historical evolution of permanent gullies in the Myjava Hill Land, Slovakia', Catena, 51, pp. 223-239. doi: 10.1016/S0341-8162(02)00167-4.

Stokes, A. et al. (2014) 'Ecological mitigation of hillslope instability: ten key issues 
facing researchers and practitioners', Plant Soil, 377, pp. 1-23. doi: 10.1007/s11104014-2044-6.

Talema, A. et al. (2017) 'Multi-criteria-based plant species selection for gully and riverbank stabilization in a sub-humid tropical area', Land Degradation \& Development, 1686(May), pp. 1675-1686. doi: 10.1002/ldr.2699.

Tebebu, T. Y. et al. (2010) 'Surface and subsurface flow effect on permanent gully formation and upland erosion near Lake Tana in the northern highlands of', Hydrol. Earth Syst. Sci., 14, pp. 2207-2217. doi: 10.5194/hess-14-2207-2010.

Thompson, R. C. and Luckman, P. G. (1993) ‘Performance of biological erosion control in New Zealand soft rock hill terrain', Agroforestry Systems, 21(2), pp. 191-211. doi: 10.1007/BF00705230.

Torri, D. and Poesen, J. (2014) 'A review of topographic threshold conditions for gully head development in different environments', Earth-Science Reviews. Elsevier B.V., 130, pp. 73-85. doi: 10.1016/j.earscirev.2013.12.006.

Vandekerckhove, L. et al. (2000) 'Characteristics and controlling factors of bank gullies in two semi-arid mediterranean environments', Geomorphology, 33, pp. 37-58. doi: 10.1016/S0169-555X(99)00109-9.

Vanmaercke, M. et al. (2016) 'How fast do gully headcuts retreat?', Earth-Science Reviews, 154, pp. 336-355. doi: 10.1016/j.earscirev.2016.01.009.

Vannoppen, W. et al. (2015) 'A review of the mechanical effects of plant roots on concentrated flow erosion rates', Earth-Science Reviews, 150, pp. 666-678. doi: 10.1016/j.earscirev.2015.08.011.

Vannoppen, W. et al. (2017) 'How do root and soil characteristics affect the erosionreducing potential of plant species?', Ecological Engineering. Elsevier, 109(January), pp. 186-195. doi: 10.1016/j.ecoleng.2017.08.001. 
Vanwalleghem, T. et al. (2005) 'Rapid development and infilling of a buried gully under cropland, central Belgium', Catena, 63(2-3), pp. 221-243. doi: 10.1016/j.catena.2005.06.005.

Vanwalleghem, T. et al. (2006) 'Prehistoric and Roman gullying in the European loess belt: a case study from central Belgium', The Holocene, 16(3), pp. 393-401. doi: 10.1191/0959683606hl935rp.

Wilkinson, S. N. et al. (2018) 'Grazing impacts on gully dynamics indicate approaches for gully erosion control in northeast Australia', Earth Surface Processes and Landforms, 43(8), pp. 1711-1725. doi: 10.1002/esp.4339.

Wilson, G. V. et al. (2008) 'Conservation practices and gully erosion contributions in the Topashaw Canal watershed', Journal of Soil and Water Conservation, 63(6), pp. 420-429. doi: 10.2489/jswc.63.6.420.

WOCAT (2020) World Overview of Conservation Approaches and Technologies. Centre for Development and Environment, Bern, Switzerland. https://qcat.wocat.net/en/wocat/.

Wolka, K., Mulder, J. and Biazin, B. (2018) 'Effects of soil and water conservation techniques on crop yield, runoff and soil loss in Sub-Saharan Africa: A review', Agricultural Water Management, 207, pp. 67-79. doi: 10.1016/j.agwat.2018.05.016.

Wright, K. R., Crowley, C. and Crowley, G. (2008) 'Erosion control at ancient Mesa Verde', Erosion Control, 15(5), pp. 58-62. Available at: https://www.scopus.com/inward/record.uri?eid=2-s2.047649133353\&partnerID=40\&md5=8e82d03d4ba73052a9b4fccdc4de51b3.

Wu, Y. et al. (2008) 'Development of gullies and sediment production in the black soil region of northeastern China', Geomorphology, 101(4), pp. 683-691. doi: 10.1016/j.geomorph.2008.03.008. 
Xiang-zhou, X., Hong-wu, Z. and Ouyang, Z. (2004) 'Development of check-dam systems in gullies on the Loess Plateau, China', Environmental Science \& Policy, 7 , pp. 79-86. doi: 10.1016/j.envsci.2003.12.002.

Xu, M. et al. (2014) 'Soil properties in natural grassland, Caragana korshinskii planted shrubland, and Robinia pseudoacacia planted forest in gullies on the hilly Loess Plateau, China', Catena, 119, pp. 116-124. doi: 10.1016/j.catena.2014.03.016.

Xu, X. et al. (2015) 'Erosion control effects of cornstalk mulching on loess hillslope with gully', Nongye Jixie Xuebao/Transactions of the Chinese Society for Agricultural Machinery, 46(8), pp. 130-137. doi: 10.6041/j.issn.1000-1298.2015.08.019.

Yitbarek, T. W., Belliethathan, S. and Stringer, L. C. (2012) 'The onsite cost of gully erosion and cost-benefit of gully rehabilitation: A case study in Ethiopia', Land Degradation and Development, 23(2), pp. 157-166. doi: 10.1002/ldr.1065.

Zegeye, A. D. et al. (2016) 'Morphological dynamics of gully systems in the subhumid Ethiopian Highlands: The Debre Mawi watershed', Soil, 2(3), pp. 443-458. doi: 10.5194/soil-2-443-2016.

Zegeye, A. D., Dessalegn, C., et al. (2018) ‘Gullies, a critical link in landscape soil loss: A case study in the subhumid highlands of Ethiopia', Land Degradation \& Development, pp. 1222-1232. doi: 10.1002/ldr.2875.

Zegeye, A. D., Langendoen, E. J., et al. (2018) 'Root reinforcement to soils provided by common Ethiopian highland plants for gully erosion control', Ecohydrology, 11(6), pp. 1-11. doi: 10.1002/eco.1940.

Zeng, Q. L. et al. (2009) 'A case study of long-term field performance of check-dams in mitigation of soil erosion in Jiangjia stream, China', Environmental Geology, 58(4), pp. 897-911. doi: 10.1007/s00254-008-1570-z.

Zhang, K., Xu, M. and Wang, Z. (2009) 'Study on reforestation with seabuckthorn in 
the Pisha Sandstone area', Journal of Hydro-environment Research, 3(2), pp. 77-84. doi: 10.1016/j.jher.2009.06.001.

Zheng, F. L. (2006) 'Effect of vegetation changes on soil erosion on the Loess Plateau', Pedosphere, 16(4), pp. 420-427. doi: 10.1016/S1002-0160(06)60071-4.

Zimale, F. A. et al. (2017) 'Improving watershed management practices in humid regions', Hydrological Processes, 31(September 2016), pp. 3294-3301. doi: 10.1002/hyp.11241.
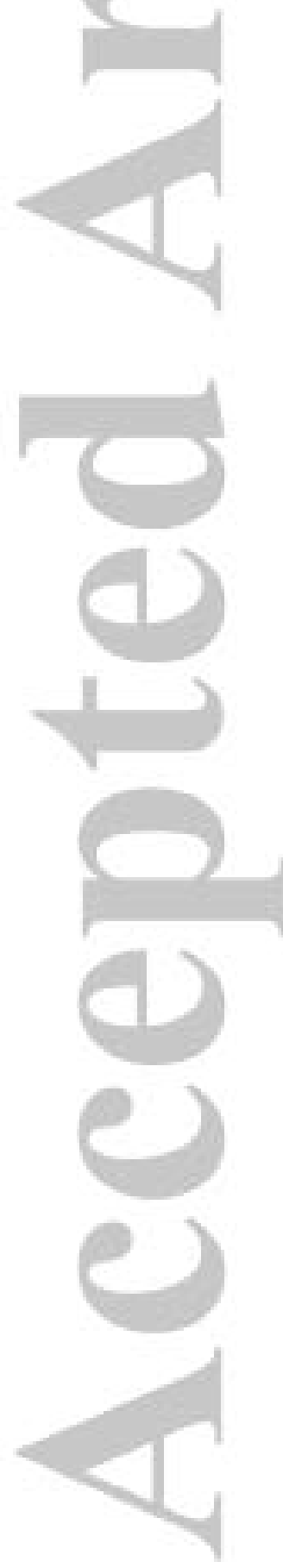

This article is protected by copyright. All rights reserved. 
Table 1: Common types of vegetation barriers to prevent gully development and their characteristics

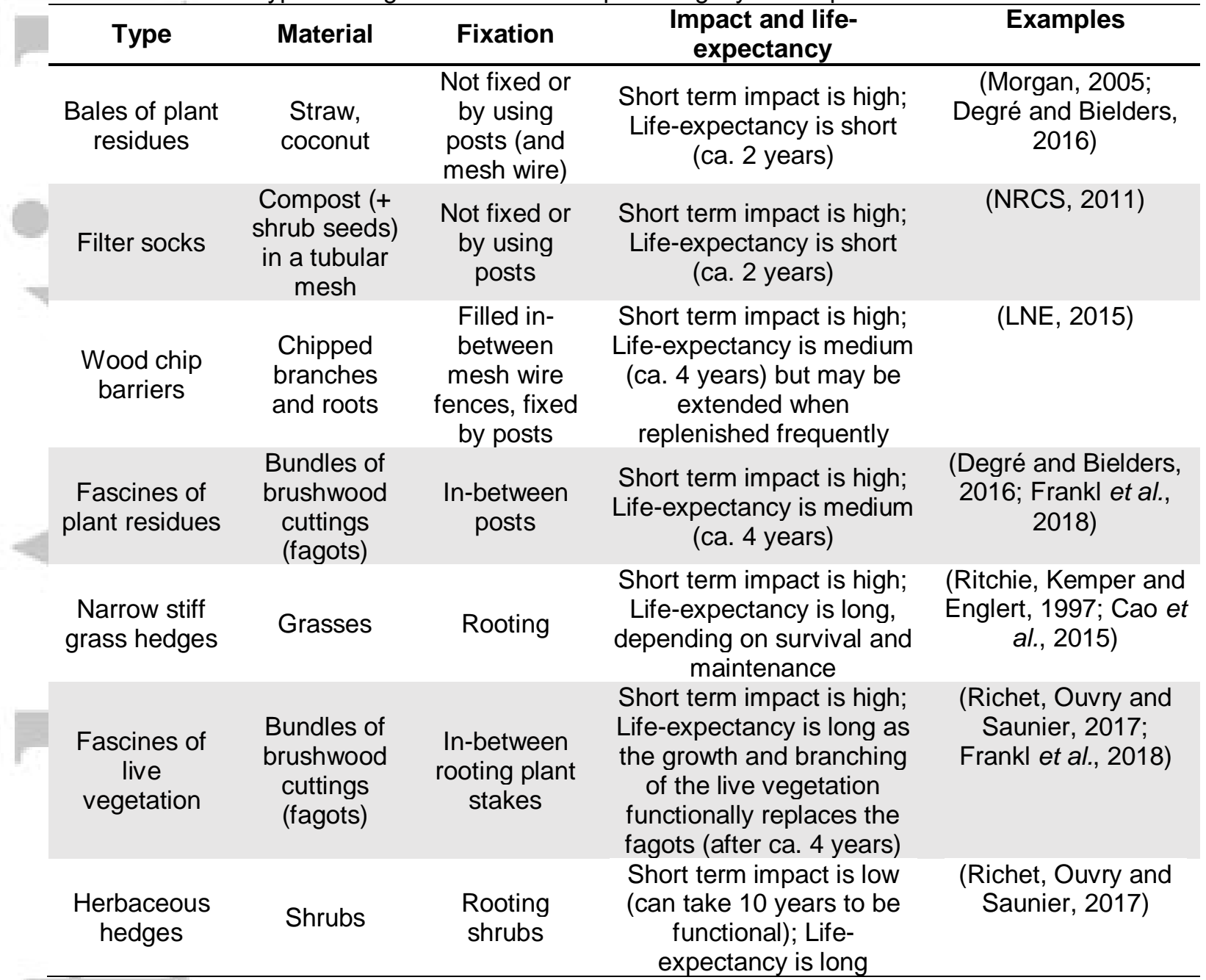

This article is protected by copyright. All rights reserved. 
Table 2: Common plant species reported in case studies used for gully control works in the eroding channels

\begin{tabular}{|c|c|c|}
\hline Bioclimate & Plants species & Reference \\
\hline Mediterranean & $\begin{array}{l}\text { Lygeum spartum Loefl. ex L.(esparto } \\
\text { grass) }\end{array}$ & Hooke and Sandercock (2012) \\
\hline $\begin{array}{l}\text { Mediterranean } \\
\text { (mountainous) }\end{array}$ & Salix alba L. (willow) & $\begin{array}{l}\text { Burylo et al. (2007), Erktan and Rey } \\
\text { (2013), Erktan et al. (2013), Rey and } \\
\text { Labonne (2015), Rey and Burylo } \\
\text { (2014) }\end{array}$ \\
\hline Subtropical & Acacia etbaica Schweinf. (acacia) & Reubens et al., (2009) \\
\hline Subtropical & Dodonaea angustifolia L.f. (sand olive) & Reubens et al. (2009) \\
\hline Subtropical & $\begin{array}{l}\text { Guadua angustifolia Kunth (guadua } \\
\text { bamboo) }\end{array}$ & Calle et al. (2013) \\
\hline Subtropical & Jatropha curcas L.(Jatropha) & Ehrensperger et al. (2015) \\
\hline Subtropical & $\begin{array}{l}\text { Pennisetum purpureum Schumach. } \\
1827 \text { (elephant grass) }\end{array}$ & $\begin{array}{l}\text { Addisie et al. (2018), Ayele et al. } \\
\text { (2016) }\end{array}$ \\
\hline Subtropical & Sesbania sesban (L.) Merr. (river hemp) & $\begin{array}{l}\text { Addisie et al. (2018); Ayele et } \\
\text { al.,(2016); Reubens et al., (2009) }\end{array}$ \\
\hline $\begin{array}{l}\text { Subtropical, } \\
\text { tropical }\end{array}$ & $\begin{array}{l}\text { Chrysopogon zizanioides L. (Vetiver } \\
\text { grass) }\end{array}$ & $\begin{array}{l}\text { Addisie et al. (2018); Ndona and } \\
\text { Truong (2006) }\end{array}$ \\
\hline $\begin{array}{l}\text { Warm } \\
\text { temperate }\end{array}$ & Dodonaea viscosa Jacq. (jarilla) & Marden et al. (2011) \\
\hline $\begin{array}{l}\text { Warm } \\
\text { temperate }\end{array}$ & Erythrina americana Mill (colorin) & Lira-Caballero et al. (2018) \\
\hline $\begin{array}{l}\text { Warm } \\
\text { temperate }\end{array}$ & Panicum virgatum L. (switchgrass) & Dabney et al. (2004) \\
\hline
\end{tabular}

This article is protected by copyright. All rights reserved. 
Table 3: Gully control by check dams and its effectiveness

\begin{tabular}{|c|c|c|c|c|c|c|c|c|c|c|c|c|}
\hline & Country & $\begin{array}{l}\text { Location } \\
\text { (catchm.) }\end{array}$ & $\begin{array}{l}\text { Cath. } \\
\text { area } \\
\text { (ha) }\end{array}$ & $\begin{array}{c}\# \\
\text { Check } \\
\text { dams }\end{array}$ & $\begin{array}{c}\text { Gully } \\
\text { width } \\
(\mathrm{m})^{\star}\end{array}$ & $\begin{array}{l}\text { Implement } \\
\text {-ed since }\end{array}$ & $\begin{array}{l}\text { Monitoring } \\
\text { interval } \\
\text { (yr.) }\end{array}$ & $\begin{array}{l}\text { Breach } \\
\text {-ed (\%) }\end{array}$ & $\begin{array}{l}\text { Total } \\
\text { sediment } \\
\text { retent. per } \\
\text { check dam } \\
(\mathrm{Mg})^{\star}\end{array}$ & $\begin{array}{l}\text { Annual } \\
\text { sediment } \\
\text { retent. per } \\
\text { check dam } \\
\left(\mathrm{Mg} \mathrm{yr}^{-1}\right)\end{array}$ & $\begin{array}{l}\text { Catchment } \\
\text { sediment } \\
\text { yield } \\
\text { reduct. } \\
\text { (Mg ha- } \\
\left.{ }^{1} \mathrm{yr}^{-1}\right)\end{array}$ & Reference \\
\hline \multirow{3}{*}{$\frac{\text { 它 }}{\frac{1}{4}}$} & Ethiopia & $\begin{array}{l}\text { Amhara (Ene- } \\
\text { Chilala) }\end{array}$ & 26 & 4 & 3 & 2013 & 2 & 0.0 & 5300.00 & 662.50 & 203.8 & $\begin{array}{c}\text { Ayele et al. } \\
\text { (2016) }\end{array}$ \\
\hline & Ethiopia & Tigray & ca. 200 & 29 & 4.6 & 2014 & 1 & 37.9 & $x$ & $x$ & $x$ & $\begin{array}{l}\text { Nyssen et } \\
\text { al. (2017) }\end{array}$ \\
\hline & Ethiopia & Tigray (Geba) & 647 & 400 & 5 & 1998 & 2 & 39.0 & $x$ & $x$ & $x$ & $\begin{array}{l}\text { Nyssen et } \\
\text { al. (2004) }\end{array}$ \\
\hline \multirow{5}{*}{ 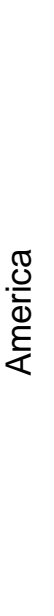 } & Ecuador & $\begin{array}{l}\text { Cuenca } \\
\text { (Loreto) }\end{array}$ & 0.42 & 12 & 1.5 & 2011 & 1 & $x$ & 2.85 & 2.85 & $\begin{array}{l}81.5(- \\
77 \%)\end{array}$ & $\begin{array}{c}\text { Borja et al. } \\
\text { (2018) }\end{array}$ \\
\hline & Ecuador & $\begin{array}{l}\text { Cuenca } \\
\text { (Loreto) }\end{array}$ & 2.4 & 35 & 1.5 & 2011 & 1 & $x$ & 16.90 & 16.90 & $\begin{array}{l}15.7(- \\
86 \%)\end{array}$ & $\begin{array}{c}\text { Borja et al. } \\
\text { (2018) }\end{array}$ \\
\hline & Mexico & $\begin{array}{l}\text { Sinaloa } \\
\text { (Culiacan) }\end{array}$ & $x$ & 273 & 6.5 & 2011 & $3-5$ & 27.1 & 32.04 & 8.01 & $x$ & $\begin{array}{c}\text { Lucas- } \\
\text { Borja et al. } \\
\text { (2018) }\end{array}$ \\
\hline & Mexico & $\begin{array}{l}\text { Sierra Madre } \\
\text { del Sur }\end{array}$ & $x$ & $x$ & small & 2015 & $x$ & $x$ & $x$ & $x$ & $4.1(-39 \%)$ & $\begin{array}{l}\text { Lira- } \\
\text { Caballero } \\
\text { et al. } \\
\text { (2018) }\end{array}$ \\
\hline & USA & Arizona & 4 & 27 & $\begin{array}{c}\text { ca. } 1 \text { - } \\
3\end{array}$ & 2008 & 5 & 3.7 & 2.75 & 0.92 & $6.2(-48 \%)$ & $\begin{array}{l}\text { Polyakov } \\
\text { et al. } \\
\text { (2014) }\end{array}$ \\
\hline
\end{tabular}

This article is protected by copyright. All rights reserved. 


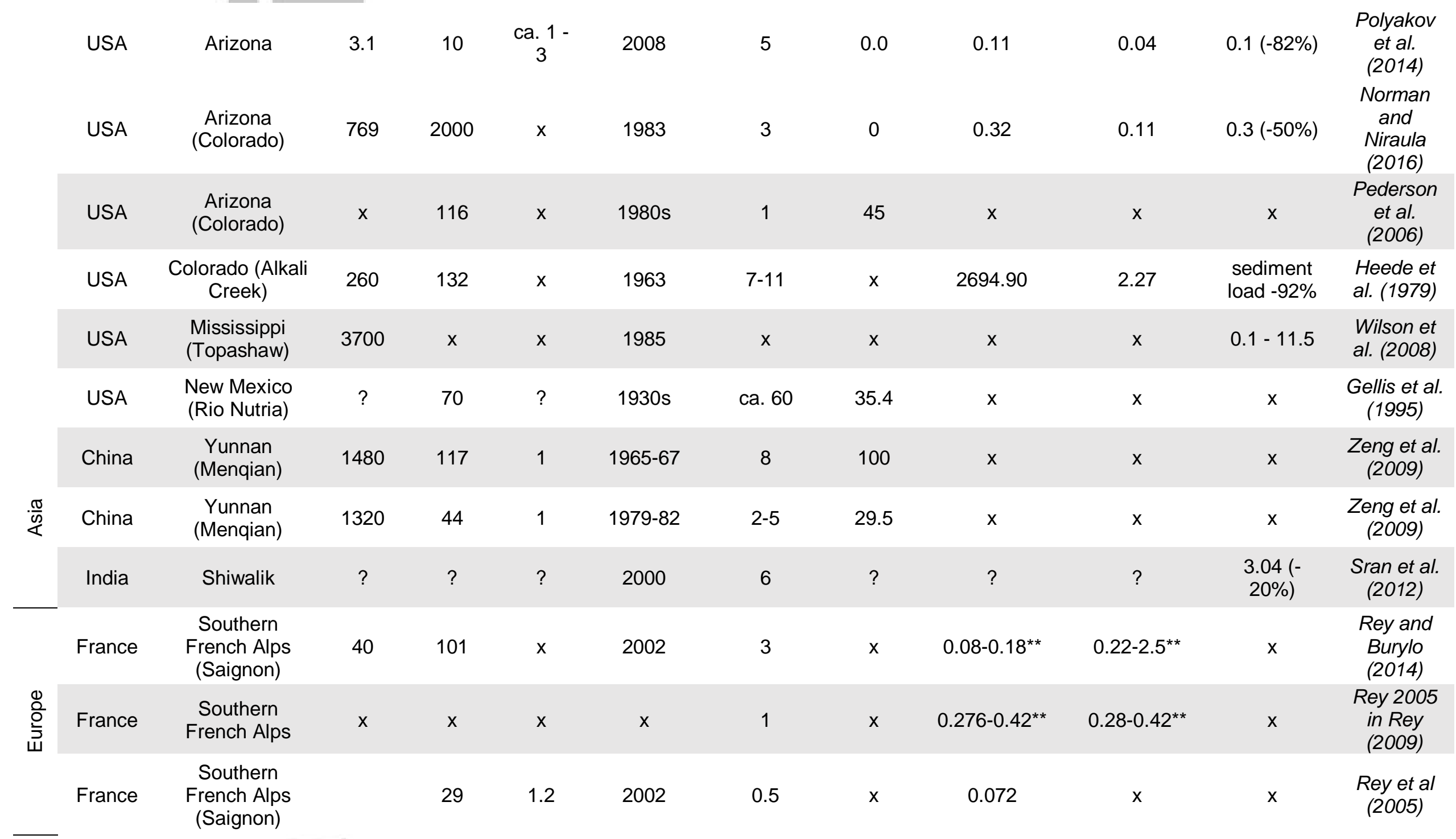




\begin{tabular}{|c|c|c|c|c|c|c|c|c|c|c|c|}
\hline Greece & $\begin{array}{c}\text { Cassandra } \\
\text { (Chanioti and } \\
\text { N. Skioni) }\end{array}$ & 953 & $x$ & small & 2006 & 1.5 & 5.9 & $x$ & $x$ & $\begin{array}{c}\text { sediment } \\
\text { load - } 11 \text { to } \\
25 \%\end{array}$ & $\begin{array}{l}\text { Aristeidis } \\
\text { and } \\
\text { Vasiliki } \\
\text { (2015) }\end{array}$ \\
\hline Spain & $\begin{array}{l}\text { Almeria (Betic } \\
\text { Cordillera) }\end{array}$ & 2890 & 36 & $x$ & $1960 s$ & $16-39$ & $x$ & $x$ & $x$ & $\begin{array}{l}10.1(- \\
72 \%)\end{array}$ & $\begin{array}{l}\text { Bellin et al. } \\
\text { (2011) }\end{array}$ \\
\hline Spain & Ávila (Tórtoles) & ca. 200 & 113 & 11 & 1966 & 48 & $x$ & 65.65 & 1.37 & $5.6(-91 \%)$ & $\begin{array}{c}\text { Díaz- } \\
\text { Gutiérrez } \\
\text { et al. } \\
\text { (2019) }\end{array}$ \\
\hline Spain & $\begin{array}{l}\text { Palencia } \\
\text { (Saldaña) }\end{array}$ & $\begin{array}{c}\text { ca. } \\
37.5\end{array}$ & 25 & 9.3 & $1930 \mathrm{~s}$ & ca. 80 & $x$ & $x$ & $x$ & $\begin{array}{c}10.9(-91 \\
\%)\end{array}$ & $\begin{array}{l}\text { Ramos- } \\
\text { Diez et al. } \\
\text { (2016) }\end{array}$ \\
\hline Spain & Ávila (Tórtoles) & ca. 200 & 25 & 14 & 1966 & 48 & $x$ & $x$ & $x$ & $9(-98 \%)$ & $\begin{array}{l}\text { Ramos- } \\
\text { Diez et al. } \\
\text { (2016) }\end{array}$ \\
\hline Spain & Ávila (Corneja) & 428 & 30 & 11 & $1960 s$ & ca. 53 & $x$ & $x$ & $x$ & $5.9(-92 \%)$ & $\begin{array}{l}\text { Mongil- } \\
\text { Manso et } \\
\text { al. (2019) }\end{array}$ \\
\hline Spain & $\begin{array}{l}\text { Iberian Range } \\
\text { (Ribagorda) }\end{array}$ & 9.23 & 3 & 20.7 & 2008 & 6 & $x$ & 1266.67 & 211.11 & 114 & $\begin{array}{l}\text { Martín- } \\
\text { Moreno et } \\
\text { al. (2014) }\end{array}$ \\
\hline Spain & $\begin{array}{c}\text { Murcia } \\
\text { (Cárcavo) }\end{array}$ & 2732 & 36 & 13.6 & $1970-80 s$ & $35-45$ & 5.6 & 34.33 & 0.86 & 0.01 & $\begin{array}{l}\text { Castillo et } \\
\text { al. (2007) }\end{array}$ \\
\hline \multirow[t]{2}{*}{ Spain } & $\begin{array}{c}\text { Murcia/Albacete } \\
\text { (Taibilla) }\end{array}$ & 32000 & 120 & large & 1973 & 27 & 22 & 16.37 & 0.61 & $3.3(-30 \%)$ & $\begin{array}{c}\text { Quiñonero- } \\
\text { Rubio et } \\
\text { al. (2016) }\end{array}$ \\
\hline & & & & & & $\begin{array}{c}n= \\
\text { median= }\end{array}$ & $\begin{array}{c}14 \\
24.39\end{array}$ & $\begin{array}{c}15 \\
16.37\end{array}$ & $\begin{array}{c}14 \\
1.36\end{array}$ & $\begin{array}{c}23 \\
6.05\end{array}$ & \\
\hline
\end{tabular}

* When reported in $\mathrm{m}^{3}$, an average bulk density was used for conversion.

** Average used from range for median calculation 
Table 4: Check dam failure and its solution (references and explanation see text)

\section{Key reasons of check dam failures}

- Inappropriate design

- Poor construction and/or implementation

- Excessive height (unstable, plunge pool erosion)

- Steep gully bed slope (high flow energy)

- Dam abrasion by sediment-laden runoff

- Bypass flow (due to soil piping)

- Catchment area increasing runoff volume

- Gully is in a 'cut' phase

\section{Main solutions to improve the sustainability of check dams}

Adjust design

- More permeable structures using brushwood, loose rocks, etc. (Pederson, Petersen and Dierker, 2006; Schwindt et al., 2018; Nichols and Polyakov, 2019);

- Structures dissipating runoff energy such as log dams (Böll et al., 2009; Aristeidis and Vasiliki, 2015; Nyssen et al., 2017);

- Structures which intercept subsurface flow when soil piping may cause dam bypass flow (Frankl et al., 2016);

- Structures more resistant to abrasive flows (boulder-faced) (Nyssen et al., 2017).

\section{Use vegetation}

- As a bioengineering structure in which vegetation is an integral part of the check dam, and thus part of the rehabilitation strategy (Rey, 2004, 2018);

- To stabilize the gully in-between check dams, in combination with additional measures such as channel reshaping and protection against, for example, gazing (Reubens et al., 2009);

- To stabilize the gully head, in combination with additional measures such as flow diversion (in a forest) or head reshaping (into cropland) and applying a protective ground cover (Poesen, 1989; Sheng and Liao, 1997; Addisie et al., 2018). 
Table 5: Case studies that demonstrate the positive effects of control measures on gully network development.

\begin{tabular}{|c|c|c|c|c|}
\hline Country & $\begin{array}{c}\text { Reduction } \\
\text { in gully } \\
\text { length }\end{array}$ & Time span & Comments & Reference \\
\hline $\begin{array}{c}\text { New } \\
\text { Zealand }\end{array}$ & $42 \%$ & $10-30$ years & $\begin{array}{l}\text { mainly for } \\
\text { gullies less } \\
\text { than } 5 \mathrm{~m} \\
\text { deep }\end{array}$ & $\begin{array}{c}\text { Thompson } \\
\text { and } \\
\text { Luckman } \\
\text { (1993) }\end{array}$ \\
\hline N Ethiopia & $25 \%$ & ca. 20 years & $\begin{array}{l}\text { mainly } \\
\text { effective on } \\
\text { first-order } \\
\text { reaches }\end{array}$ & $\begin{array}{l}\text { Frankl et al. } \\
\text { (2013) }\end{array}$ \\
\hline Tunisia & $9 \%$ & 52 years & $\begin{array}{c}\text { compared to } \\
\text { a marked } \\
\text { increase of } \\
\text { gully length } \\
\text { by } 66 \% \text { in } \\
\text { untreated } \\
\text { zones }\end{array}$ & $\begin{array}{c}\text { (Rebai, } \\
\text { Raclot and } \\
\text { Ouezdou } \\
\text { (2013) }\end{array}$ \\
\hline
\end{tabular}

This article is protected by copyright. All rights reserved. 


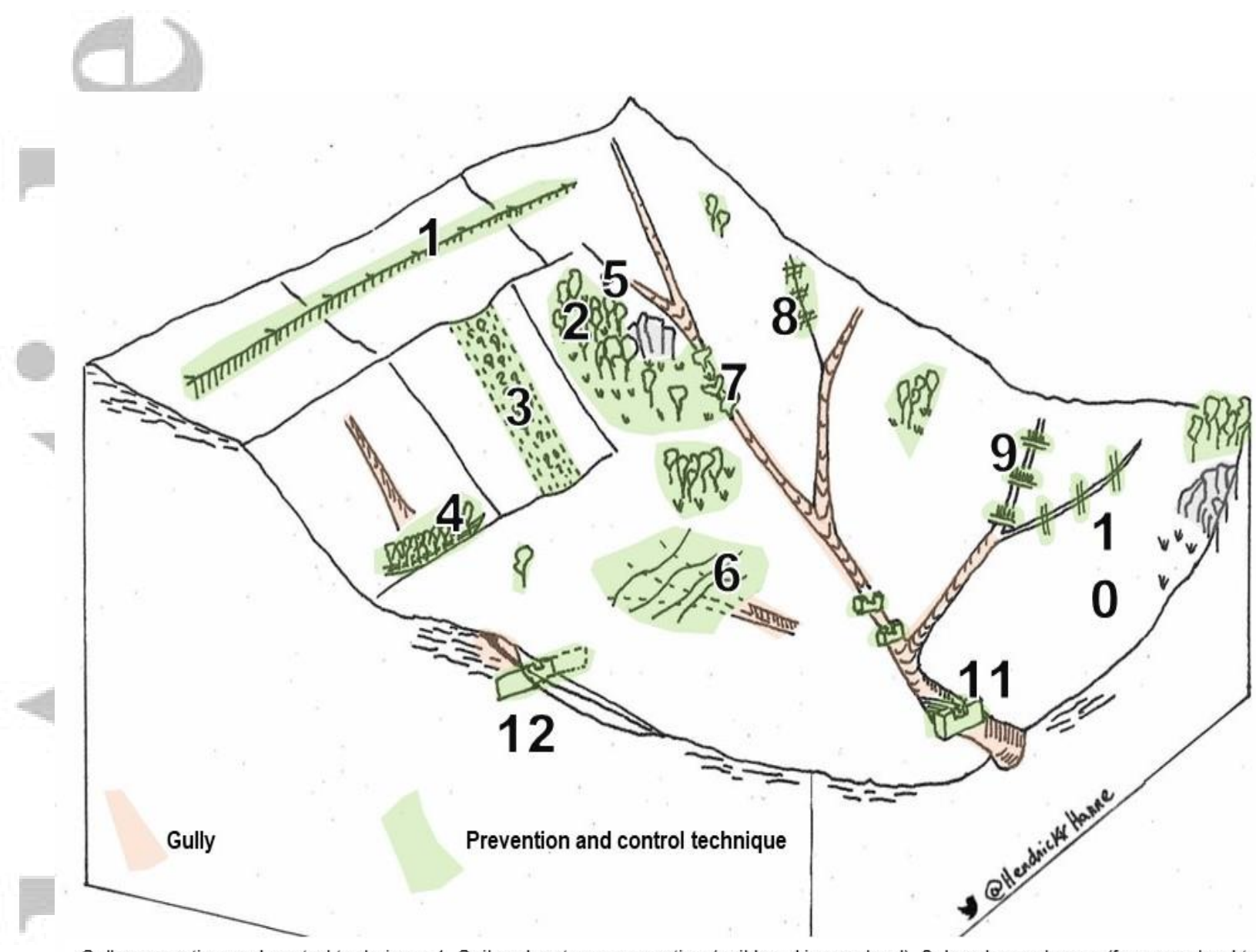

Gully prevention and control technique: 1. Soil and water conservation (soil bund in cropland), 2. Land use change (from cropland to forest), 3. Topsoil resistance in concentrated flow zone (grassed waterway), 4. Vegetation barrier at recurrent ephemeral gully site (fascine made of life vegetation), 5. Runoff diversion into forest, 6 . Gully reshaping and filling, 7. Gully channel vegetation, 8. Brushwood check dams, 9. Bioengineered check dams (log dam + live vegetation), 10. Log dams, 11. Loose rock / gabion check dam (chnwind channel anrradatinn) 12. Sulusııfare nenmemhrane dam tn hlork hunascinn nf rherk dams raused hu cnil nininn

Figure 1: Overview of gully prevention and control techniques discussed in this paper. 

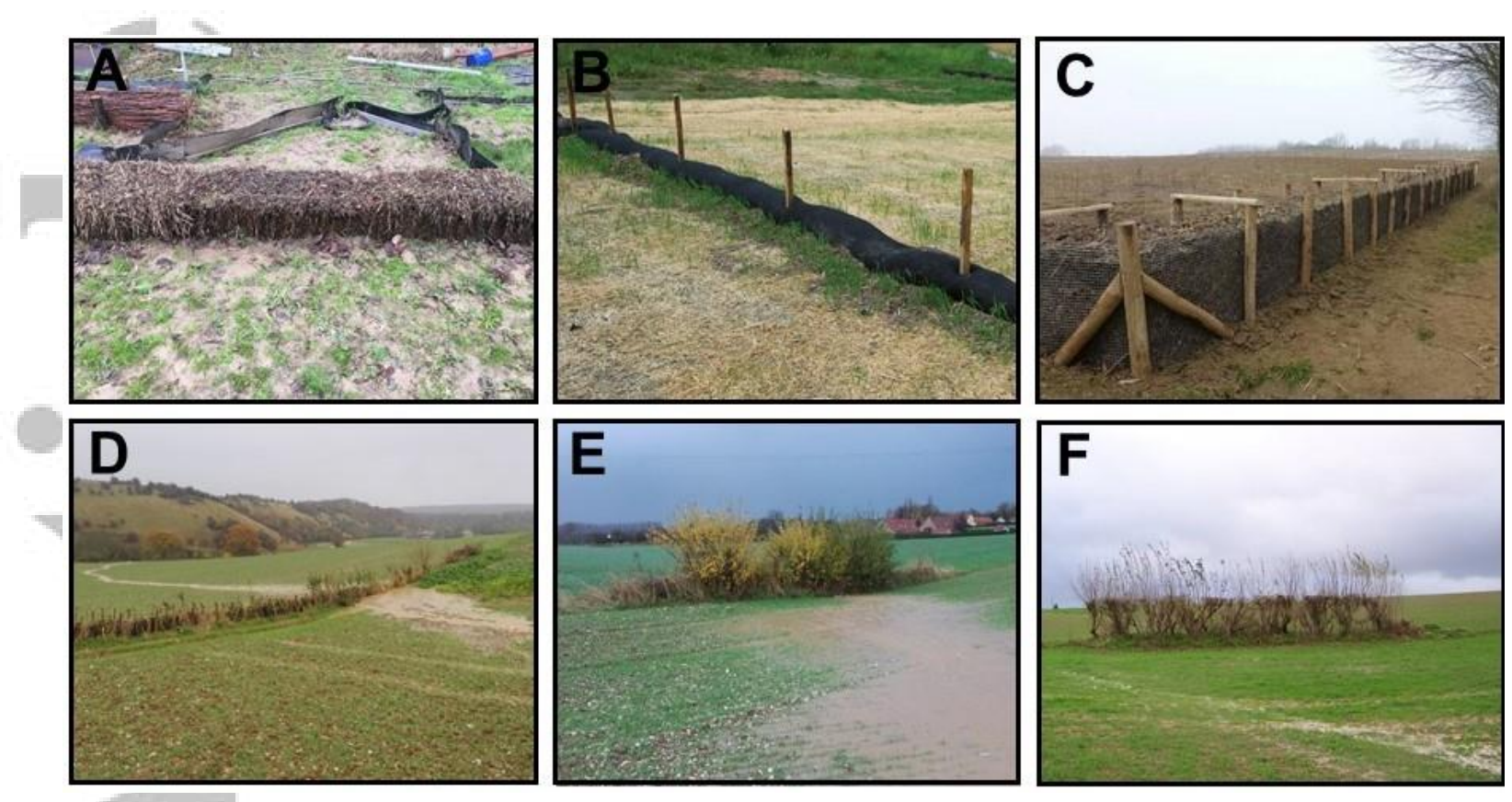

Figure 2: Examples of vegetation barriers made of plant residues, $A$ : straw bale (Belgium), B: filter socket (U.K.), C: woodchip (Belgium), D: fascine made of plant residues (France), and made of life vegetation, E: live fascine (France), F: hedgerow (France). Photographs A, C-F @ A. Frankl, B ( SteelNation.com. 


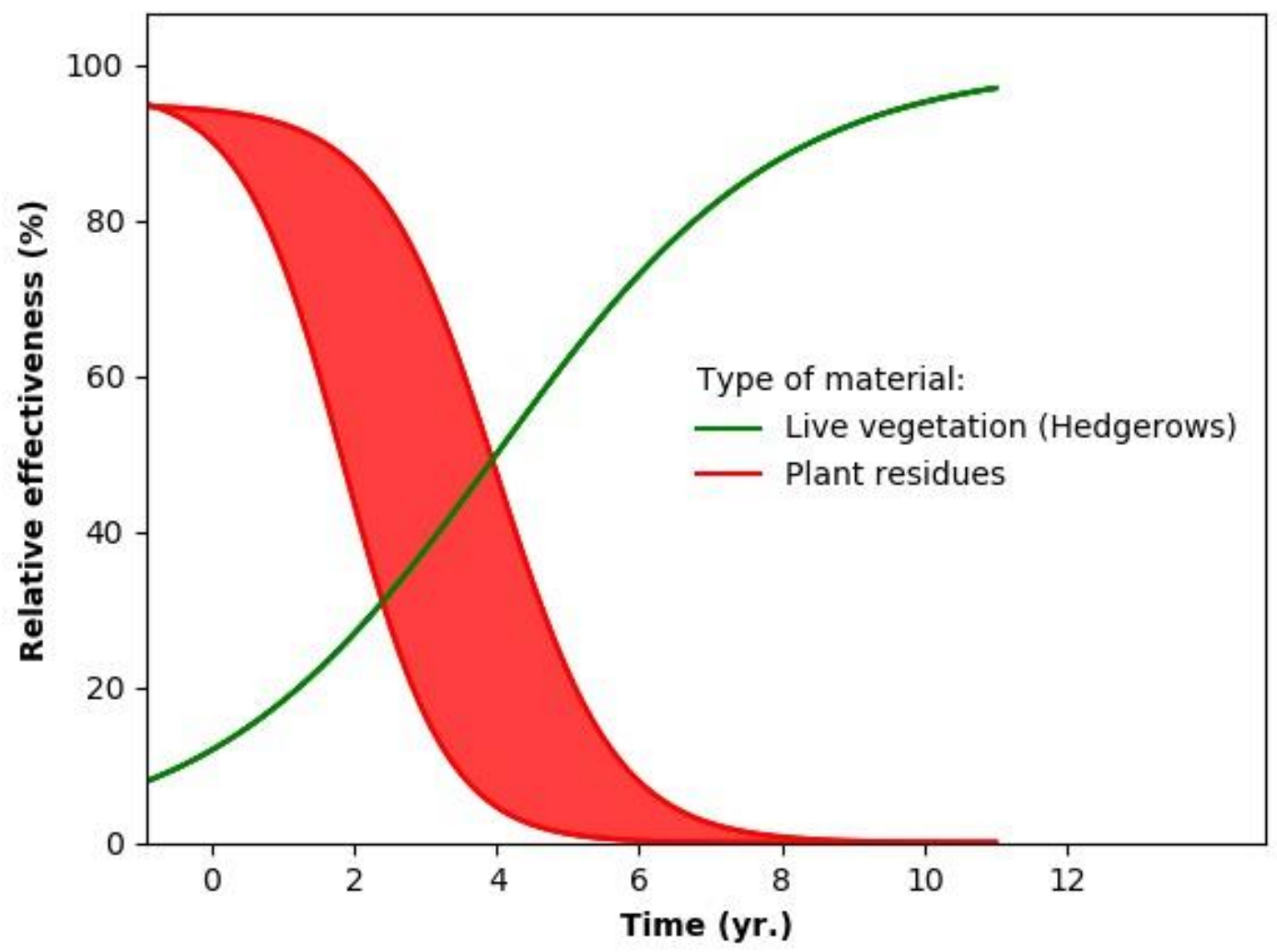

Figure 3: Effectiveness of vegetation barriers in controlling ephemeral gully erosion (modified from Ouvry et al., 2012) 

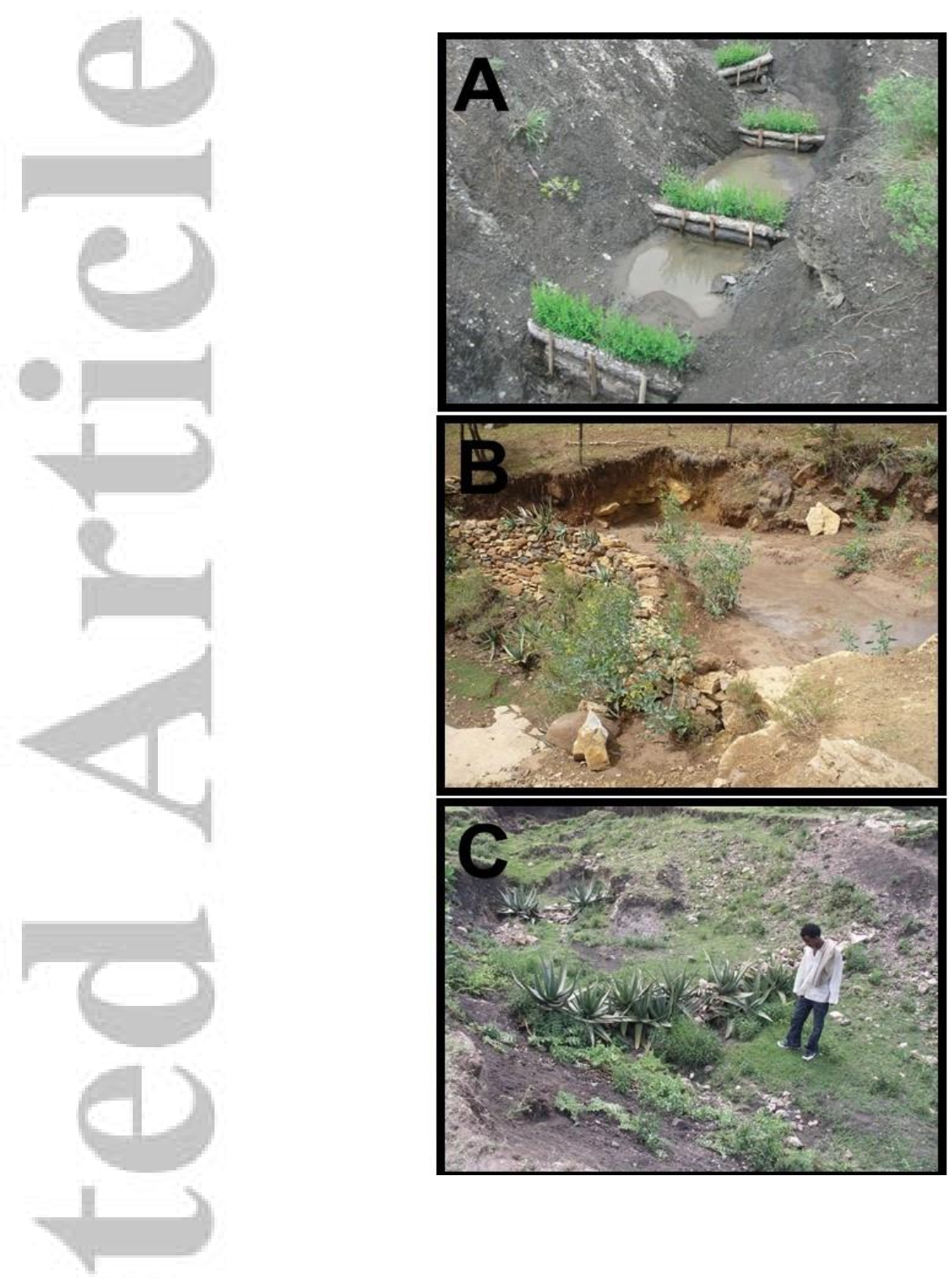

Figure 4: Examples of gully rehabilitation methods combining check dams and vegetation. A: Bioengineered check dams made of woods logs that dissipate the flow energy across the channel width, and planted with a brush layer of Salix alba L. (willow) cuttings, B: Loose rock check dam which facilitates spontaneous bush growth (Ethiopia). C: Loose rock check dam, reinforced with Aloe plants, in gully channel cut in vertisol (Ethiopia). (A: @ https://blogs.egu.eu/, B: @) A. Frankl. C: @J. Poesen).

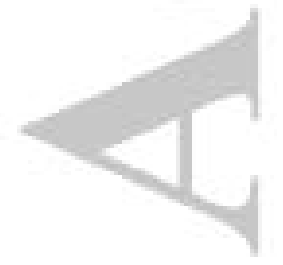

This article is protected by copyright. All rights reserved. 


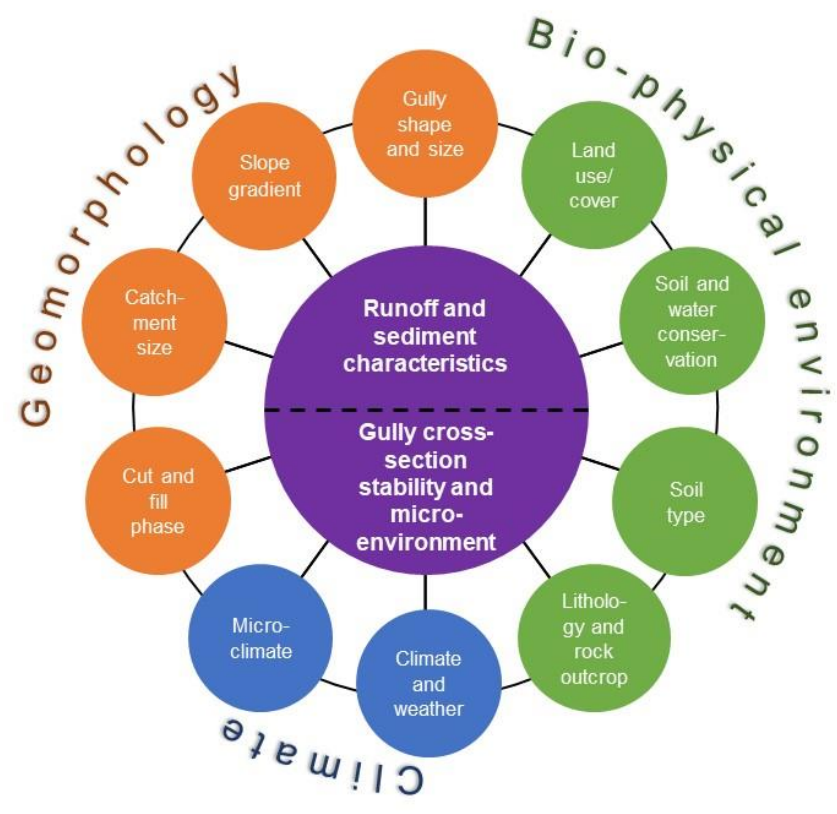

Figure 5: Factors controlling success or failure rates of gully control and their driving forces. 


\section{Gully 'cut-and-fill' cycle:}

Cut

Degradation Degradation/Aggradation Aggradation

\section{Success rate and value for money of control measures:} Low High

Check dams ('hard' engineering)

Vegetation ('soft' engineering)

Figure 6: Illustration of the relationship between gully channel development and the application of gully control measures

This article is protected by copyright. All rights reserved. 


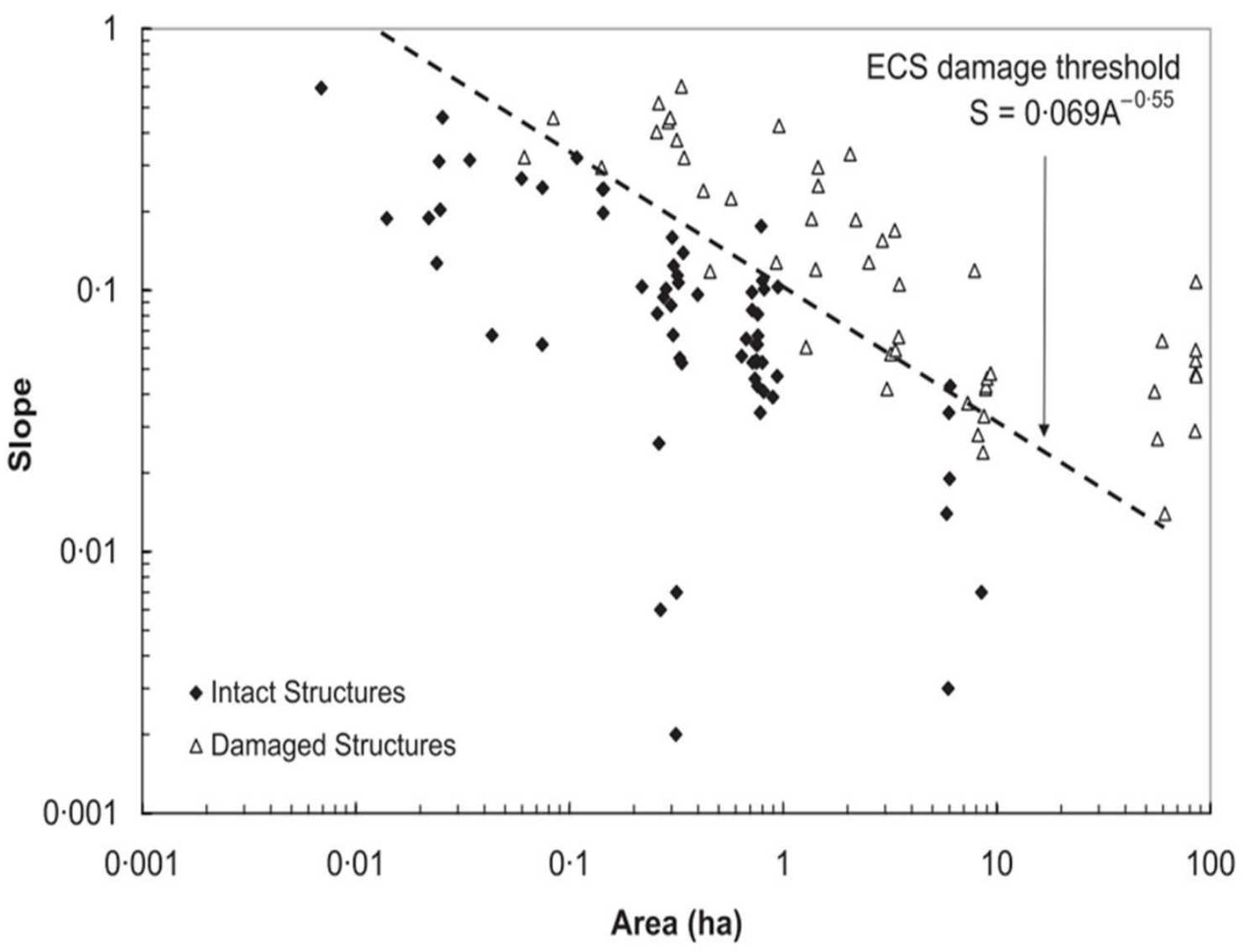

Figure 7: Slope - area threshold for check dams (ECS, erosion control structures) developed for a dryland environment (Grand Canyon) in the USA. Reprinted from Pederson et al. (2006). 


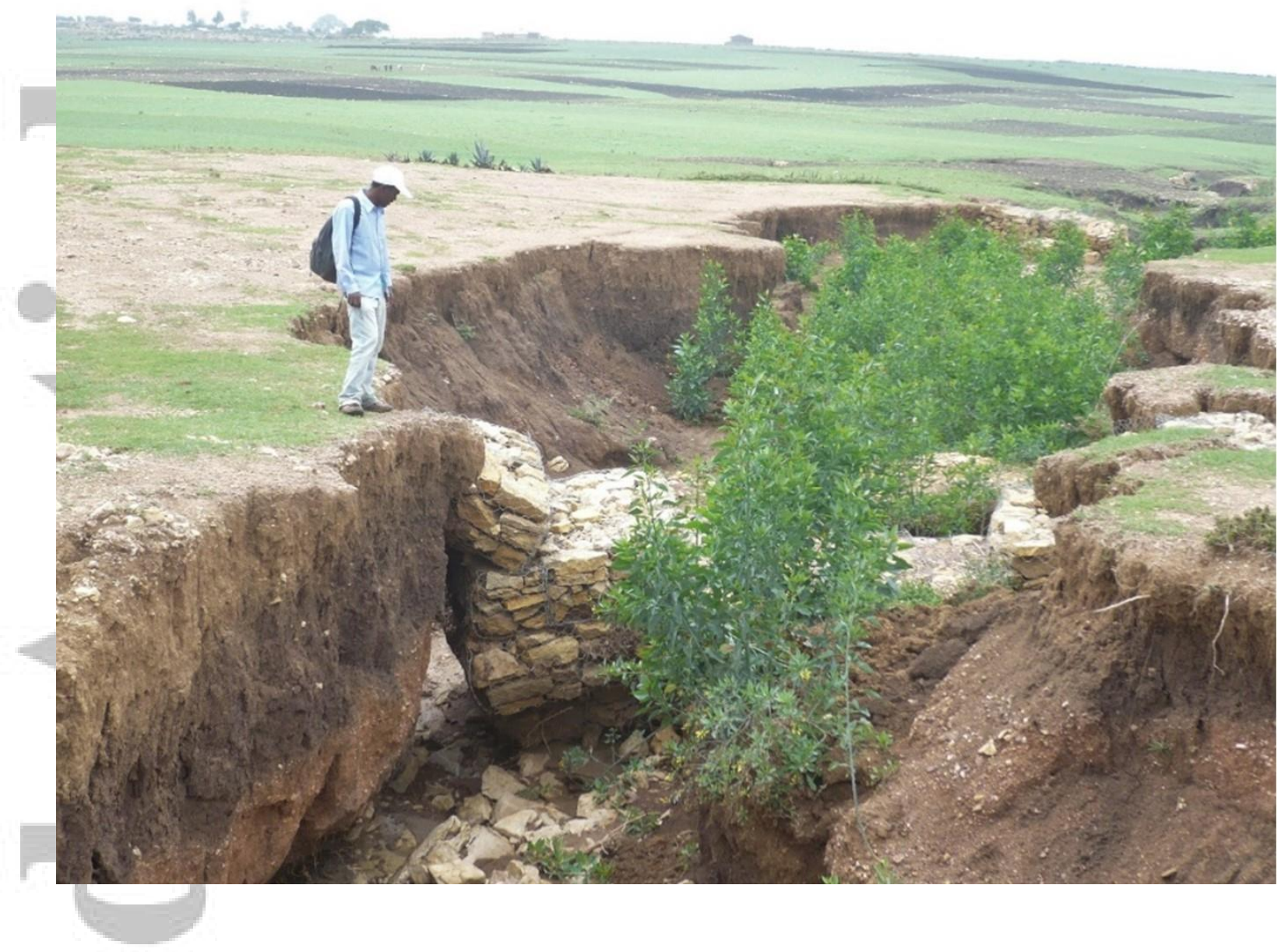

Figure 8: Dispersive soils are a main reason for check dam failure. The check dam allowed the establishment of Nicotiana glauca shrubs (a woody weed) on the gully bank, but because the flow bypassed the gabions at a Vertisol lens, the gully reincised. The gully banks are now steep and undercut, ready to collapse. (Ethiopia, (C) A. Frankl).

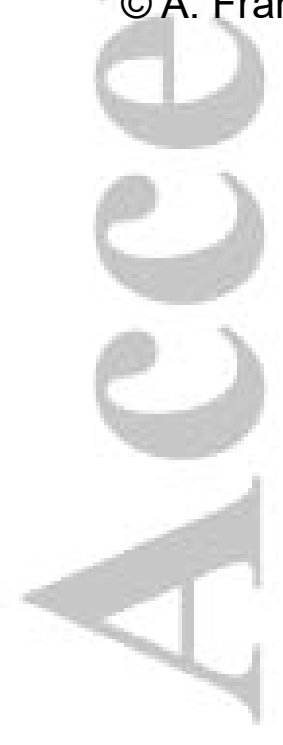

This article is protected by copyright. All rights reserved. 

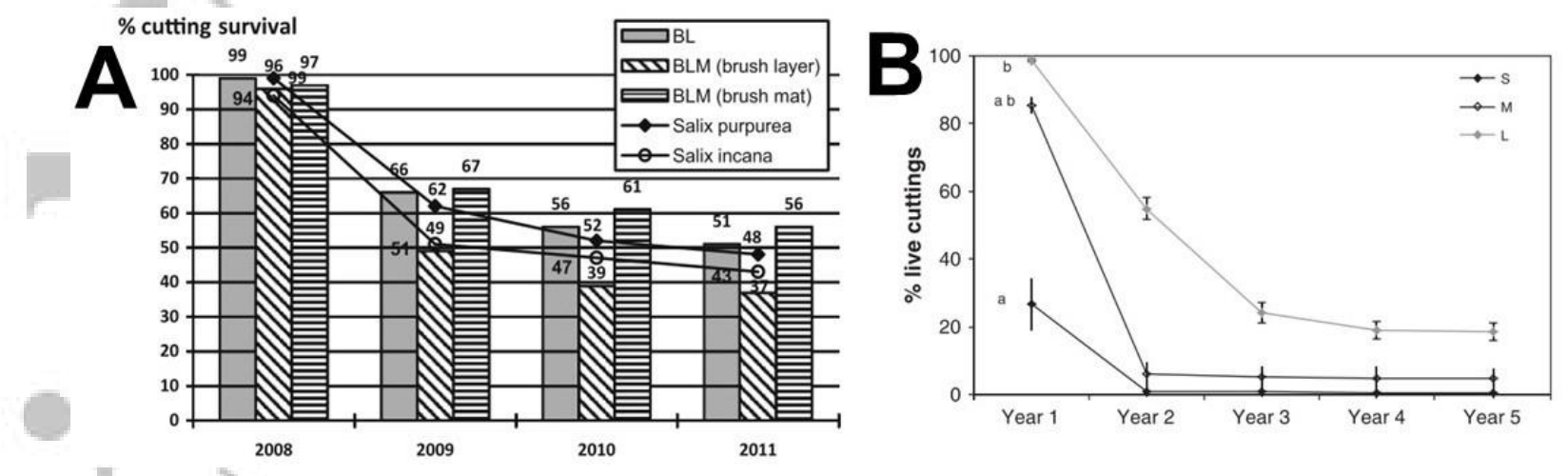

Figure 9: Willow cuttings survival rates at bioengineering works in the Southern French Alps. For $A$ and $B$, cuttings are applied as brush layers $(B L)$ (+ brush mat $B L M)$ on wooden sills (see figure Figure 7B). In both cases, survival rates stabilize from the third year onwards. In $B$, the gully catchment size $(S=$ small, $M=$ moderate, $L=$ large), negatively affects survival rates. A: reprinted from Rey and Labonne (Rey and Labonne, 2015), B: reprinted from Rey and Burylo (2014) 